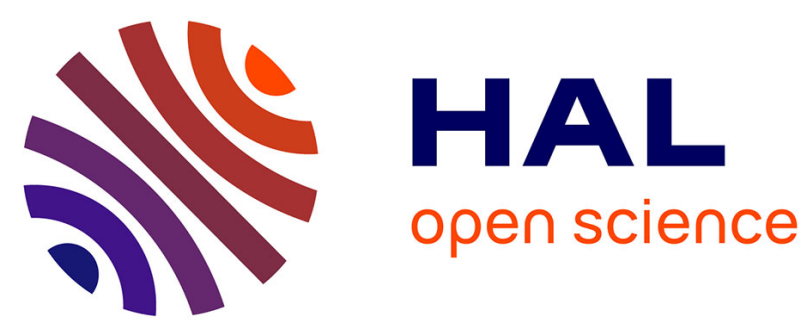

\title{
An integrated approach combining soil profile, records and tree ring analysis to identify the origin of environmental contamination in a former uranium mine (Rophin, France)
}

A. Martin, Y. Hassan-Loni, A. Fichtner, O. Péron, Karine David, P. Chardon, S. Larrue, A. Gourgiotis, S. Sachs, T. Arnold, et al.

\section{To cite this version:}

A. Martin, Y. Hassan-Loni, A. Fichtner, O. Péron, Karine David, et al.. An integrated approach combining soil profile, records and tree ring analysis to identify the origin of environmental contamination in a former uranium mine (Rophin, France). Science of the Total Environment, 2020, 747, pp.141295.

10.1016/j.scitotenv.2020.141295 . hal-03095931

\section{HAL Id: hal-03095931 \\ https://hal.science/hal-03095931}

Submitted on 19 Jan 2022

HAL is a multi-disciplinary open access archive for the deposit and dissemination of scientific research documents, whether they are published or not. The documents may come from teaching and research institutions in France or abroad, or from public or private research centers.
L'archive ouverte pluridisciplinaire HAL, est destinée au dépôt et à la diffusion de documents scientifiques de niveau recherche, publiés ou non, émanant des établissements d'enseignement et de recherche français ou étrangers, des laboratoires publics ou privés.

\section{(ㅇ)(1) $\$$}

Distributed under a Creative Commons Attribution - NonCommercial - NoDerivatives| 4.0 
1 An integrated approach combining soil profile, records and tree ring analysis

2 to identify the origin of environmental contamination in a former uranium mine (Rophin, France)

4 A. Martin a, Y. Hassan-Loni ${ }^{a}$, A. Fichtner ${ }^{a, b}$, O. Péron ${ }^{a}, *$, K. David ${ }^{a}$, P. Chardon ${ }^{c}$, S. Larrue ${ }^{d}$,

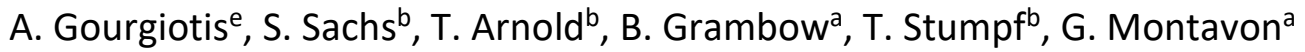

${ }^{b}$ Helmholtz-Zentrum Dresden - Rossendorf, Institute of Resource Ecology,

11 Bautzner Landstraße 400, 01328 Dresden, Germany 


\section{Highlights}

- Origin of contamination near Rophin tailings storage site: natural vs. anthropogenic

- A whitish silt loam soil layer in a wetland was associated with a high U content.

- Dating and records indicate that $\mathrm{U}$ was deposited during previous mining activities.

- U mineral particles transported by turbid waters were deposited in a wetland.

- Dendroanalysis shows an uptake of ${ }^{238} \mathrm{U}$ linked to the mining activity period.

\section{Abstract}

Uranium mining and milling activities raise environmental concerns due to the release of radioactive and other toxic elements. Their long-term management thus requires a knowledge of past events coupled with a good understanding of the geochemical mechanisms regulating the mobility of residual radionuclides. This article presents the results on the traces of anthropic activity linked to previous uranium (U) mining activities in the vicinity of the Rophin tailings storage site (Puy de Dôme, France). Several complementary approaches were developed based on a study of the site's history and records, as well as on a radiological and chemical characterization of soil cores and a dendrochronology. Gamma survey measurements of the wetland downstream of the Rophin site revealed a level of $1,050 \mathrm{nSv} \cdot \mathrm{h}^{-1}$. Soil cores extracted in the wetland showed $\mathrm{U}$ concentrations of up to $1,855 \mathrm{mg} \cdot \mathrm{kg}^{-1}$, which appears to be associated with the presence of a whitish silt loam (WSL) soil layer located below an organic topsoil layer. Records, corroborated by prior aerial photographs and analyses of ${ }^{137} \mathrm{Cs}$ and ${ }^{14} \mathrm{C}$ activities, suggest the discharge of $U$ mineral particles while the site was being operated. Moreover, lead isotope ratios indicate that contamination in the WSL layer can be discriminated by a larger contribution of radiogenic lead to total lead. The dendroanalysis correlate $U$ emissions from 
43 Rophin with the site's history. Oak tree rings located downstream of the site contain

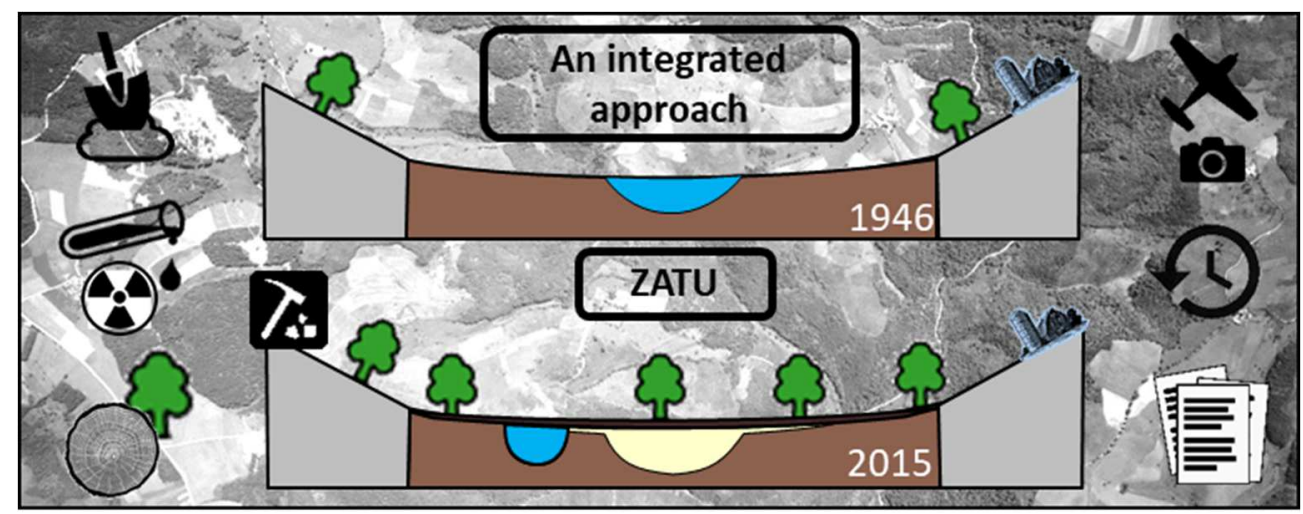

uranium concentrations ten times higher than values measured on unaffected trees.

Moreover, the highest $U$ concentrations were recorded not only for the operating period, but more surprisingly for the recent site renovations as well. This integrated approach corroborates that $U$ mineral particles were initially transported as mineral particles in Rophin's watershed and that a majority of the deposited uranium appears to have been trapped in the topsoil layer, with high organic matter content.

\section{Graphical abstract}

53 processing plants, raise environmental concerns due to the possible release of radioactive

\section{Keywords}

Uranium mining, wetland, records, dendroanalysis, radiochronology, U decay chain.

\section{Introduction}

Uranium $(U)$ is a key resource that has been mined in France for use in the nuclear energy industry from 1948 to 2001. Uranium mining and milling activities, as well as mineral and other potentially toxic elements (Ljungberg and Öhlander, 2001; Lottermoser and 
Ashley, 2005). The impact of $U$ release into the environment is governed by the $U$ speciation, which influences its solubility, mobility and bioavailability (Abdelouas, 2006). In areas unaffected by human activity, the inflow of $U$ is considered to be primarily related to its dissolved or colloidal species; in the vicinity of mines on the other hand, its transport can also occur in the form of $U$ mineral particles. Even though in Western Europe most $U$ mines were shut down over the course of the past few decades, these former mines and especially their associated tailings storage sites are subject to continuous environmental monitoring (Ballini et al., 2020). In addition to the environmental monitoring of storage sites, it is also critical to consider the environment potentially contaminated near the mines. This consideration becomes even more important since the land may now be privately owned (Mangeret et al., 2018).

In the vicinity of $U$ mines, wetlands prove to be particular natural zones since they act as physical particle and metal traps. Numerous studies have indeed found highly increased U concentrations in wetlands, extending into the several thousand $\mathrm{mg} \cdot \mathrm{kg}^{-1}$; this observation has been recorded in areas affected by mining activities (Li et al., 2014; Mangeret et al., 2018; Schöner et al., 2009; Wang et al., 2014) as well as areas with granitic bedrock subjected to naturally elevated $U$ concentrations in groundwater (Mikutta et al., 2016; Owen and Otton, 1995; Regenspurg et al., 2010; Zielinski et al., 1986). The accumulation of $U$ is explained by complexation with organic matter (OM) present at high concentrations in wetlands (Bordelet et al., 2018) and/or by reduction of U(VI) to scarcely soluble U(IV) due to strongly reducing conditions related to the bacterial degradation of plant material (Alessi et al., 2012; Cumberland et al., 2016; Lovley et al., 1991; Nakashima et al., 1984; Newsome et al., 2015). However, it must be noted that the observed contaminations may be of natural 
origin, without the involvement of any human action. Weathering and erosion of the local bedrock, which is often granitic in the case of French $U$ mines, can also play a major role in increasing these concentration levels. High $U$ contents have in fact already been documented at sites not heavily impacted by mining activities, such as Alpine soils (up to $\left.4,000 \mathrm{mg} \cdot \mathrm{kg}^{-1}\right)$, or by ground and surface waters, where the surrounding bedrock mainly consists of crystalline rocks that commonly contain trace amounts of $U$ (Gourgiotis et al., 2020).

It is essential to not only report any past contamination linked to uranium mining, but also trace the origin of such contamination over these sites, i.e. natural vs. anthropogenic. This question corresponds to the focus of this article combining different approaches, featuring both direct knowledge of past events and an analysis of the records or characterization of environmental indicators like soil and vegetation.

In the absence of first-hand recollections of details surrounding the period of operations (Le Berre and Bretesché, 2019), the knowledge of past contaminations requires a rigorous study of historical evidence, mostly documents (regulatory and technical reports) and, ideally, a direct consultation of various records like raw data without operator interpretation. For example, a study of site history combined with satellite images or previous aerial photographs has been used to determine how tailings were deposited in ponds, e.g. disposal of tailings at the Cominak mine in Niger (Déjeant et al., 2016) or at the Bois Noirs mine in France (Chautard et al., 2020).

Concerning the soil analysis, an initial possibility consists of correlating the observed contaminations with dating approaches, i.e. ${ }^{137} \mathrm{Cs}$ and/or ${ }^{14} \mathrm{C}$ (Cuvier et al., 2016). It should be noted that excessive use of ${ }^{210} \mathrm{~Pb}$ is unfortunately impossible in a $\mathrm{U}$ mining context (Reyss 
et al., 2016). The origin of these $U$ markings, whether natural or anthropogenic, can then

107 also be traced by means of lead isotopy (Bollhöfer, 2012; Bollhöfer et al., 2006; Cuvier et al., 108 2016; Gourgiotis et al., 2020).

109 Concerning vegetation, past contaminations can be retrieved through dendroanalysis. This 110 step consists of measuring the distribution of trace elements in the annual growth rings of 111 trees; it is based on the assumption that trace elements remain immobile once deposited in 112 the stem. Such a premise has raised controversy in the literature (Hagemeyer, 2000; Nabaisa 113 et al., 1999). The method has been implemented on a variety of tree species in order to 114 correlate trace metal concentrations with the pollution history at various locations 115 (Beramendi-Orosco et al., 2013; Pearson et al., 2005; Watmough and Hutchinson, 1996). The 116 Cornish oak, Quercus petraea, has been repeatedly reported as a suitable indicator of 117 changes in bioavailable trace metal concentrations in an environment with trees over time 118 (Cutter and Guyette, 1993; Jonsson et al., 1997; Perone et al., 2018). Furthermore, oak tree 119 rings have been tested for use in biomonitoring uranium (Edmands et al., 2001), specifically 120 in the vicinity of former mining activities (Märten et al., 2015; Monticelli et al., 2009). This 121 approach however accounts for contamination by soluble, hence bioavailable, metals with 122 root capture generally being predominant (Lepp, 1975).

123 In summary, several complementary approaches are possible, each providing information, to 124 characterize the origin of past contaminations. The ambition of this work is therefore to 125 combine all these approaches to assess the origin of a contaminated wetland around the 126 Rophin site (Puy-de-Dôme, France). Among the 16 sites chosen to store $U$ waste in France 127 (IRSN, 2018) and, as such, classified as an ICPE installation necessitating environmental 128 protections, it was recently integrated into France's network of pilot study zones, under the 
ZATU (Zone Atelier Territoires Uranifères) created in 2015. This network is part of the Long-

130 Term Ecosystem Research ongoing in Europe (Bretagnolle et al., 2019). In this work, the

131 results obtained from surface gamma surveys are compared with soil core analyses (lead

132 isotopy, dating approaches, uranium and decay products) and dendrochronology, as well

133 with information obtained from mine operating history through reliance on different sources

134 in order to reconstitute the events leading to the current state of the Rophin site and its

135 immediate environs.

\section{2. Study site}

137 The Rophin site lies within the Forez range east of the Limagne Graben, in the northeastern

138 part of the Puy de Dôme department, close to the city of Lachaux (Fig. S1) and was among

139 several mines referenced as Western Lachaux ore bodies (Fig. S2). In this area, the mean

140 annual, temperature is $10.1^{\circ} \mathrm{C}$ with mean annual precipitations of $800 \mathrm{~mm} \mathrm{y}^{-1}$ (Météo-

141 France, www.meteofrance.com). In the global context, Western Lachaux ore bodies appear

142 as exceptional due to the predominance of parsonsite $\left(\mathrm{Pb}_{2}\left(\mathrm{UO}_{2}\right)\left(\mathrm{PO}_{4}\right)_{2}, 2 \mathrm{H} 2 \mathrm{O}\right)$ under a

143 workable deposit rather than an alteration product of pitchblende. The ore bodies are

144 hosted by coarse-grained peraluminous granite of the alkaline type, like "Bois Noirs" granite,

145 situated at the end of Variscan orogeny (Fig. S1). These bodies consist of low-temperature

146 silica/quartz containing uranyl phosphate minerals, mainly parsonsite and, at the oxidized

147 ore surface, both autunite $\left(\mathrm{Ca}\left(\mathrm{UO}_{2}\right)_{2}(\mathrm{PO} 4)_{2}, 8-12 \mathrm{H}_{2} \mathrm{O}\right)$ and tobernite $\left(\mathrm{Cu}\left(\mathrm{UO}_{2}\right)_{2}\left(\mathrm{PO}_{4}\right)_{2}, 12 \mathrm{H}_{2} \mathrm{O}\right)$

148 (Greffoy and Sarcia, 1955; Himeur and Andres, 2012). The principal events in the history of

149 the Rophin mine have been summarized in a timeline (Fig. 1) with further details in Fig. S3. 


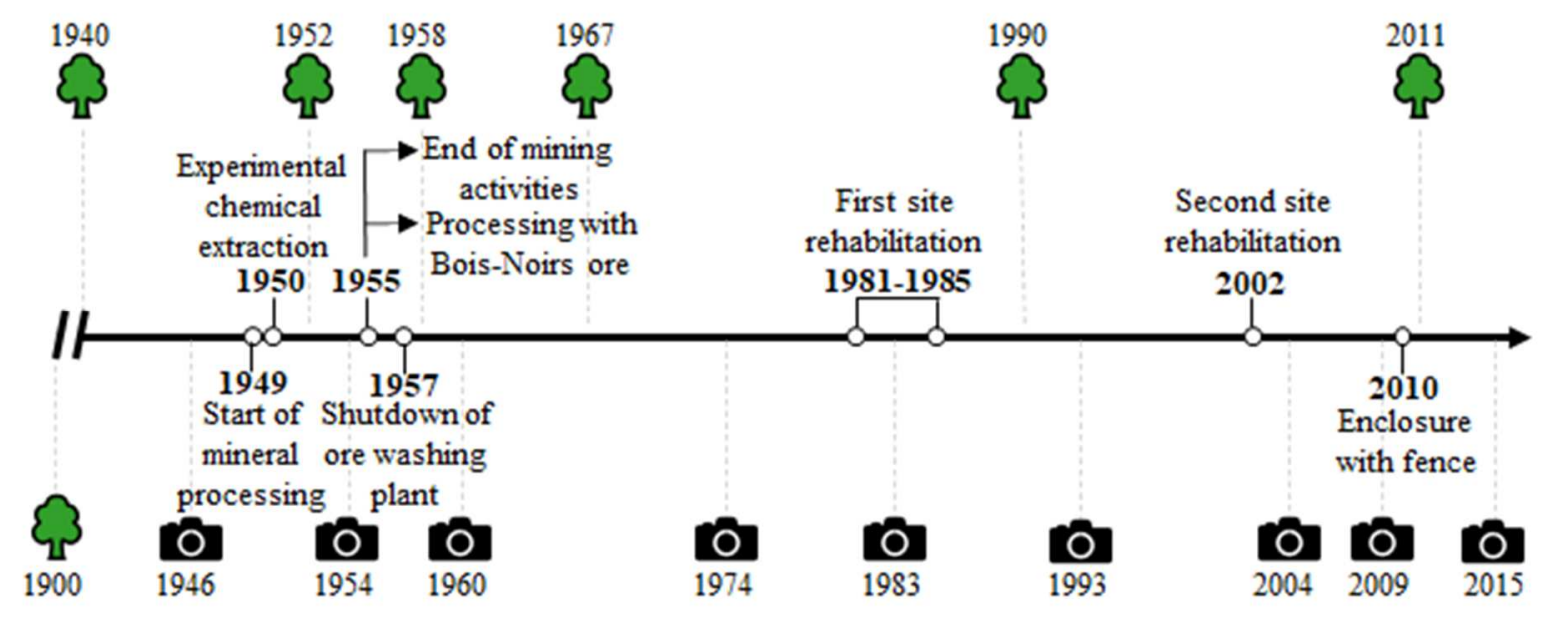

151 Fig. 1: Timeline of Rophin mine operations with time-stamped aerial photographs (Fig. S6)

152 and the sampling strategy for tree ring analysis

153 To treat the materials extracted in the Western Lachaux sector, a mechanical ore washing

154 plant was built in 1948 next to the Rophin mine (Fig. S4 and Fig. S5). At first, ore treatment

155 was gravimetric with a vibrating table, crushing machines and a flotation circuit that

156 included 3 settling ponds to retain $U$ particles (Himeur and Andres, 2012). In all, fewer than

15730 tons of $U$ were extracted from mine tailings, at a mean concentration rate of $0.7 \%$, and

158 then exported as $4.4 \%$ concentrates. Over 30,000 tons of mine and mill tailing waste were

159 stored on the site of the former processing plant (ICPE, see hachured area in Fig. 2).

160 Nowadays, the storage site is covered by vegetated soil, and forest vegetation is growing at

161 the top of the mine waste storage heap. Periodic water effluents from the underground 162 galleries are collected in a trench located in the western part of the Rophin ICPE. These 163 effluents join the "Le Gourgeat" stream heading in a NW-S direction; the stream is 164 connected to the five local ore bodies in the same watershed and moreover contributes to 165 the formation of a local wetland 200 m downstream of the Rophin site (Fig. S4). During the 166 period of mining operations, the Gourgeat watershed was closed $2 \mathrm{~km}$ downstream of the 167 Rophin site by a dam used as a water storage reservoir for water supply of the upper ore 
168

169

170

171

172 detected in the trench collecting effluent waters running inside the ICPE, with values at

173 times reaching $200 \mu \mathrm{g} . \mathrm{L}^{-1}$ (Himeur and Andres, 2012).

174 The former Rophin mine has been chosen as study site for a variety of reasons. It is now

175 uninhabited where vegetation grows on mine tailings, stored in situ, coupled with the

176 presence of a creek (Gourgeat) running in the watershed and a wetland downstream of the

177 storage area. The site offers a framework for conducting multidisciplinary scientific

178 investigations on life under natural radioactivity in ZATU context.

\section{Materials and Methods}

\subsection{Methodology for studying the history of mining operations}

181 Generally speaking, French $U$ mine operations have often been overlooked by residents (Le 182 Berre and Bretesché, 2019), and former operators (CEA, COGEMA, AREVA and now ORANO) 183 owned most of the records. In an effort to retrace the history of site operations as accurately 184 as possible, several data sources were consulted:

185 (i) A compilation of data retracing the site history through: the operator's archivist and mine 186 specialists (Guiollard, 2002), regulatory reports on environmental monitoring (Himeur, 2010; 187 Himeur and Andres, 2012), technical reports on mine operations (Greffoy and Sarcia, 1955), 188 and other independent environmental associations (Commission for Independent Research and Information on RADiation and the Puy de Dôme environment association). 
(ii) A direct consultation of the records held by the Auvergne-Rhône-Alpes DREAL (Regional

191 Directorate for the Environment, Land Planning and Housing) made available for onsite 192 consultation in February and March 2017. These documents contain raw uninterpreted data 193 from operators, including administrative and regulatory documents, inspection reports, 194 correspondence between operators and oversight agencies, press articles and documents 195 relative to mine operations (map, fees, etc.). A summary of the documents consulted, 196 arranged in chronological order, is available in Fig. S3, Fig. S5 and Table S14.

197 (iii) A collection of aerial photographs available from the "Geoportail" database (National 198 Geographic Institute (IGN)), allowing for observations of the site before, during and after 199 mining operations (Fig. S6). Nine archived aerial photographs, with a spatial resolution of 50 $200 \mathrm{~cm} \cdot$ pixel $^{-1}$ and a planimetric accuracy of less than $2 \mathrm{~m}$, were projected into a WGS84 (World 201 Geodetic System 1984) using QGIS (Quantum Geographic Information System).

202 The results from the analysis of these selected documents, that enable tracing the history of 203 site operations, will be summarized in the following section (3.1). These data will then be 204 discussed in light of field measurement results obtained from our two centers of interest, i.e. 205 wetland soils and tree rings.

\subsection{Sampling strategy}

207 An environmental monitoring and sampling campaigns were carried out between 2014 and 2082018 (Fig. 2). 


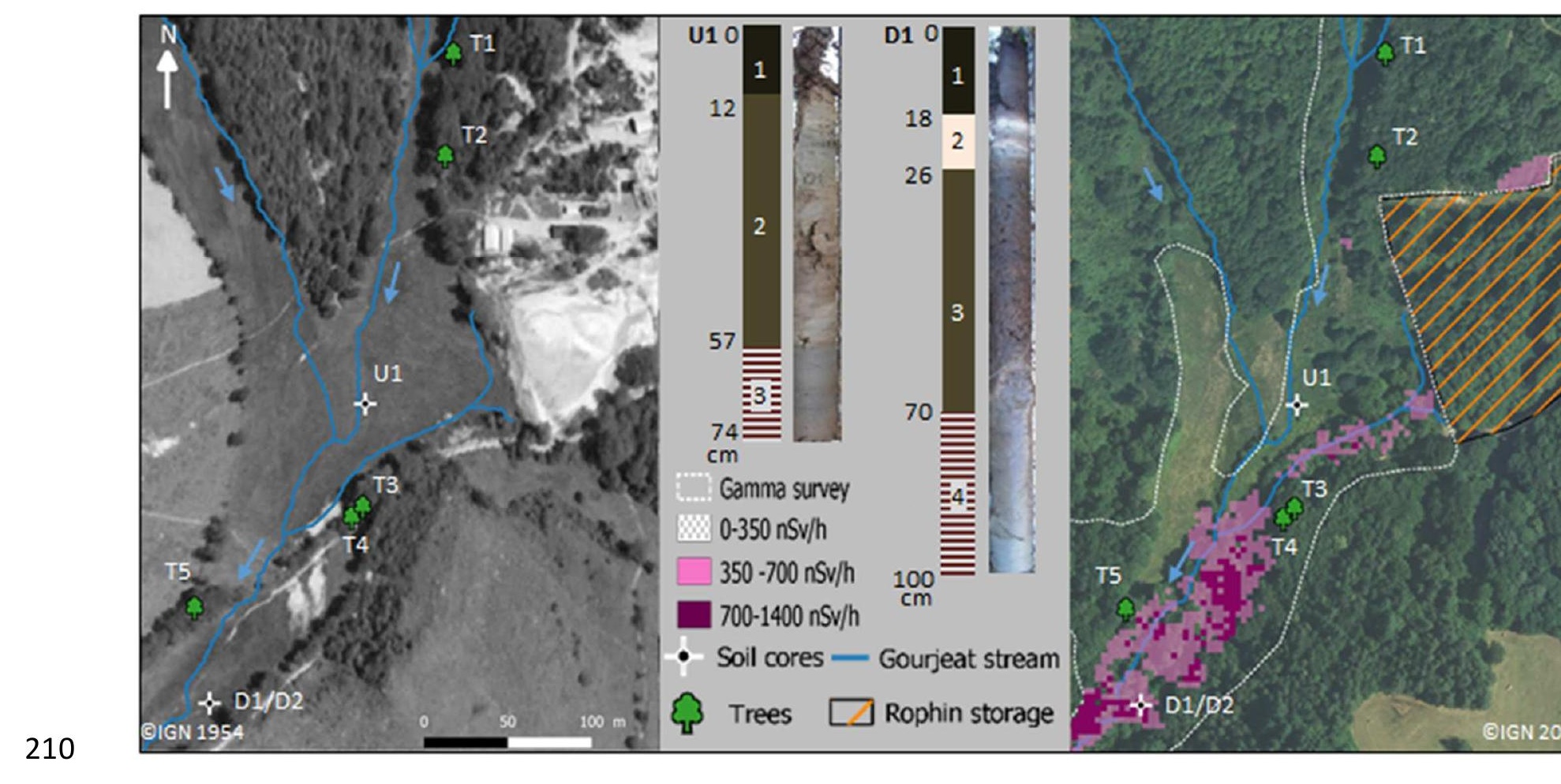

211 Fig. 2: Overview of the Gourgeat watershed with sampling locations. Left: Aerial photograph (1954) 212 with the Rophin mine processing plant. Right: Aerial photograph (2015) of the ICPE site with 213 interpolated gamma dose rates. Center: Photographs and soil profile descriptions of cores U1 and D1 214 over 74 and $100 \mathrm{~cm}$. A second core (D2) with a higher vertical resolution was collected in April 2018.

\subsubsection{Gamma survey}

216 A radiological survey of the Gourgeat watershed was performed to provide an overview of

217 the dose rate distribution at the periphery of the ICPE site open to the public. Dose-rate

218 mapping (Fig. 2 and Fig. S4) was obtained with SG-2R gamma-ray sensors (Canberra, Inc.).

219 The device used coupled the gamma-ray sensor (energy range: $59 \mathrm{keV}$ to $1.5 \mathrm{MeV}$, and

220 measurement range: $10 \mathrm{nSv} \cdot \mathrm{h}^{-1}$ to $1 \mathrm{mSv} \cdot \mathrm{h}^{-1}$ ) with a Colibri ${ }^{\oplus}$ device (Canberra, Inc.) featuring

221 an integrated GPS. Data were acquired automatically every $5 \mathrm{~s}$ or $30 \mathrm{~s}$ directly in dose rate,

222 and the sensors were placed approx. $1 \mathrm{~m}$ above ground. The measurements were conducted

223 during 5 field campaigns, from December 2014 to June 2018, across different areas. The

224 measured data points, reported in nSv.h $\mathrm{h}^{-1}\left(80-1,050 \mathrm{nSv} \cdot \mathrm{h}^{-1}\right)$, were interpolated with the 
225 inverse distance weighting method (distance coefficient $=5$ ) using the QGIS software 226 interpolation tool.

\subsubsection{Soil sampling}

228 Two soil cores were collected in January 2016 at locations upstream (Core U1) and 229 downstream (Core D1) of the hydraulic system (Fig. 2) in place to assess the environmental 230 footprint of the Rophin site with a Russian corer $100 \mathrm{~cm}$ long and $5 \mathrm{~cm}$ in diameter 231 (Eijkelkamp). Cores U1 and D1 were brought back to the laboratory, subsampled with a 232 cleaned ceramic blade the next day into $2-\mathrm{cm}$ sections under laboratory atmosphere and 233 lyophilized for gamma spectrometry analysis, ${ }^{14} \mathrm{C}$ dating and lead isotopy. A second 234 downstream core (D2) with a greater vertical resolution (Fig. 2) was collected in April 2018 235 close to the D1 location (Fig. S5c) with an in-house corer developed to protect the sample in 236 a plastic tube (8.5-cm inner diameter, Fig. S7). After extraction, the core was stored at $-20^{\circ} \mathrm{C}$ 237 in a mobile freezer. Once back in the laboratory, the frozen core was cut into 1-cm slices by 238 means of a bandsaw. Two subsamples from core D2 were analyzed by Scanning Electron 239 Microscopy (SEM) and Energy Dispersive X-Ray Spectroscopy (EDS) according to the 240 methodology explained in Fig. S8 to determine location of $U$ within minerals.

241 In addition, a total of 17 cores, called the M-series, were extracted in April 2018 (Russian 242 corer, $50 \mathrm{~cm}$, Eijkelkamp) over a distance of about $300 \mathrm{~m}$ alongside the main creek running 243 from the storage site in order to provide an overview of the soil profile in the wetland (Fig. 244 S9). Following core extraction, 2 to 4 sections of approx. $5 \mathrm{~cm}$ were selected depending on 245 the soil profile, subsampled with the same protocol than for D1 core, and then stored in 250$246 \mathrm{~mL}$ plastic jars for gamma spectrometry analysis. 
248 Tree ring samples were collected from five oak trees (Quercus petraea), chosen for their age 249 estimated at more than 100 years (T1 to T5) and located between 50 and $200 \mathrm{~m}$ from the 250 former uranium mining and storage residue (Fig. 2). Trees T1 and T2, located upstream in 251 the vicinity of the storage residue, are not influenced by the Gourgeat watershed due to an 252 elevation difference exceeding $10 \mathrm{~m}$. Trees T3 and T4, growing downstream of the storage 253 residue, are located in the watershed very close to the site of water runoff from the storage 254 residue. The last tree sampled, T5, is located further away, $200 \mathrm{~m}$ downstream of the storage residue, and has no apparent connection with the watershed due to elevation 256 difference (Fig. 2, Fig. 6 and Table S10).

257 Tree rings were collected on each tree using an increment borer (Pressler; inner diameter 5 $258 \mathrm{~mm}$ ). The selected trees were healthy, grew under similar surrounding natural conditions 259 and belonged to the same cohort. The samples were extracted from the trunk at roughly 1.5 $260 \mathrm{~m}$ above ground in July 2015. Sampling was performed with great care so as to avoid any 261 cross-contamination, i.e. the borer was washed with ethanol and Milli-Q water between 262 each extraction. After sampling, all cores were immediately sealed in plastic tubes and 263 transported to the laboratory for dendroanalysis. The samples were dried at room 264 temperature and polished with sandpaper to improve visibility of the growth rings. To avoid 265 any cross-ring contamination, the samples were cleaned by removing any dust with 266 compressed air. Tree ring samples were then scanned (1,600 dpi), and the CooRecorder 267 software (Larsson, 2016) was run for age determination with a final uncertainty of \pm 1 year. 268 The period covered by the tree rings ranged between 118 and 176 years (Table S10). Seven 269 different years were selected for $U$ analysis (Fig. 1): years 1900 and 1940 were chosen to 
270

271 272 rehabilitation works.

273

274

275

\subsection{Analysis}

represent the period before mining activity; 1952 for the period of operations; 1958 for the mine's closure; and 1967, 1990 and 2011 for the period subsequent to specific site

\subsubsection{Gamma spectrometry}

Soil radionuclide contents from the ${ }^{238} \mathrm{U}$ decay chain $\left({ }^{234} \mathrm{Th},{ }^{226} \mathrm{Ra},{ }^{210} \mathrm{~Pb}\right)$ were analyzed by means of gamma spectrometry. These analyses were carried out in filled petri dishes $(5 \mathrm{~cm}$ diameter, $1.5 \mathrm{~cm}$ thick) sealed in a radon protection membrane (Petri-Seal $\left.{ }^{(\mathrm{TM})}\right)$. The samples were first analyzed for 3 hours and then 10 hours for those with low activity. The gamma spectrometry was performed using HPGe-detectors (Canberra, BE4823/S) with a high purity germanium detector (Ge-crystal, 7500SL cryostat, 2002CPSL pre-amplifier) and a multichannel analyzer (MCA). Energy calibration by a ${ }^{152}$ Eu certified source (peak energy range: 122 to $1408 \mathrm{keV}$ ) has been coupled to a certified multigamma mixture for efficiency (peak energy range: 60 to $1,836 \mathrm{keV})$. A multigamma mixture $\left({ }^{241} \mathrm{Am},{ }^{109} \mathrm{Cd}{ }^{57} \mathrm{Co},{ }^{139} \mathrm{Ce},{ }^{51} \mathrm{Cr},{ }^{113} \mathrm{Sn}\right.$, ${ }^{85} \mathrm{Sr},{ }^{137} \mathrm{Cs},{ }^{60} \mathrm{Co},{ }^{88} \mathrm{Y}$ ) has been proportionally introduced so that the counts for each of the energies are equivalent. The self-absorption of gamma lines in materials was taken into account in the Labsocs software using the composition and density of a typical soil sample. All radionuclide concentrations are expressed with uncertainties at $2 \sigma$. These concentrations $\left({ }^{234} \mathrm{Th},{ }^{226} \mathrm{Ra},{ }^{210} \mathrm{~Pb}\right)$ with LD $\left({ }^{210} \mathrm{~Pb}\right)=35.2 \mathrm{~Bq} \cdot \mathrm{kg}-1 ; \mathrm{LD}\left({ }^{226} \mathrm{Ra}\right)=52.0 \mathrm{~Bq} \cdot \mathrm{kg}^{-1} ; \mathrm{LD}\left({ }^{234} \mathrm{Th}\right)=34.6$

Bq. $\mathrm{kg}^{-1}$ ) were respectively determined with the following energy signals: $63.3 \mathrm{keV}, 186.1$ $\mathrm{keV}$, and $46.5 \mathrm{keV}$. The ${ }^{238} \mathrm{U}$ sample concentrations were determined by assuming a secular equilibrium in the head of the decay chain between ${ }^{234} \mathrm{Th}$ and ${ }^{238} \mathrm{U}$. The resulting ${ }^{238} \mathrm{U}$ concentrations were calculated with a specific activity of $12,350 \mathrm{~Bq} \cdot \mathrm{g}^{-1}$. 
293 The $186.1 \mathrm{keV}$ energy signal of ${ }^{226} \mathrm{Ra}$ interferes with the $185.7 \mathrm{keV}$ energy signal of ${ }^{235} \mathrm{U}$; this 294 effect is corrected by introducing the ${ }^{235} \mathrm{U}$ concentration predicted by the natural isotopic 295 ratio from ${ }^{238} \mathrm{U}$ concentrations. The ${ }^{226} \mathrm{Ra}$ values were verified for a few samples by 296 measuring radiochemical equilibrium with its daughter nuclide ${ }^{214} \mathrm{~Pb}(295.2 \mathrm{keV}, 351.9 \mathrm{keV}$; $\left.\mathrm{LD}=13.2 \mathrm{~Bq} \cdot \mathrm{kg}^{-1}\right)$ and ${ }^{214} \mathrm{Bi}\left(609.3 \mathrm{keV}, 1120.3 \mathrm{keV}, 1764.5 \mathrm{keV} ; \mathrm{LD}=81.4 \mathrm{~Bq} \cdot \mathrm{kg}^{-1}\right)$ by using sealed samples (to prevent radon from escaping) stored for at least 3 weeks. Equilibrated samples were used for the ${ }^{210} \mathrm{~Pb}$ activity determination. In addition to analyzing the ${ }^{238} \mathrm{U}$ decay chain, the ${ }^{137} \mathrm{Cs}(661.7 \mathrm{keV})$ was measured for $24 \mathrm{~h}$ in a low-background environment, according to the protocol developed by Tedjani et al., (2016) in order to both achieve a lower limit of detection ( $2 \mathrm{~Bq} \cdot \mathrm{kg}^{-1}$ ) and perform soil dating over the depth.

\subsubsection{Water and soil organic matter content}

304 305

Water and soil organic matter (SOM) contents of soil samples were simply determined by loss on ignition; this procedure relied on the protocol found in Heiri et al., (2001). Between 5 and $10 \mathrm{~g}$ of homogenized wet samples were introduced into porcelain crucibles and first dried at $105^{\circ} \mathrm{C}$ overnight in a furnace (Nabertherm, Inc.), then heated at $550^{\circ} \mathrm{C}$ for $4 \mathrm{~h}$ to burn the organic matter. After each heating step, the crucibles were cooled to room temperature in a desiccator and weighed. SOM content was expressed relative to dry soil content, in contrast with water content, that account for the entire sample mass. The uncertainty for both measurements, expressed as a confidence interval $(2 \sigma)$, was calculated at less than $10 \%$.

\subsection{3. $\quad{ }^{14} \mathrm{C}$ dating}

Several samples from core D1 were analyzed by applying the Accelerator Mass Spectrometry (AMS) radiocarbon dating technique after graphitization. Results (in age calBP) were 
obtained by running the software OxCal V4.3.2 (Ramsey, 2017) using the IntCal13

317 atmospheric curve (Reimer et al., 2013). More detailed information is available in Table S11.

\subsubsection{Soil sample preparation and Pb HR-ICP-MS analysis}

Lead isotope ratios were analyzed on a single-collector high-resolution ICP-MS instrument

320

321

$333(2 \sigma, n=12)$ is lower by a factor ranging from 1,500 to 75,000 relative to the amount of $\mathrm{Pb}$ 334 derived from soil samples. Preliminary quantitative $\mathrm{Pb}$ analyses of the collected sample 335 fractions were carried out in order to prepare sample solutions at a Pb concentration of $2 \mathrm{ng}$ $336 \mathrm{~mL}^{-1}$ in $2 \% \mathrm{HNO}_{3}(\mathrm{v} / \mathrm{v})$ for $\mathrm{Pb}$ isotope measurements performed by means of HR-ICP-MS.

337 All stable lead isotopes $\left({ }^{204} \mathrm{~Pb},{ }^{206} \mathrm{~Pb},{ }^{207} \mathrm{~Pb},{ }^{208} \mathrm{~Pb}\right)$ and mercury isotopes $\left({ }^{201} \mathrm{Hg},{ }^{202} \mathrm{Hg}\right)$ were 338 measured with the operating and data acquisition parameters detailed in Table S12. The 
analysis sequence consisted of five replicate analyses of the unknown sample solution bracketed by five replicate analyses of a $2 \mu \mathrm{g} \cdot \mathrm{L}^{-1} \mathrm{~Pb}$ solution of the NIST SRM981 Pb isotope 341 standard with, between them, the $2 \% \mathrm{HNO}_{3}(\mathrm{v} / \mathrm{v})$ blank solution analysis. The isobaric 342 interference from ${ }^{204} \mathrm{Hg}$ on ${ }^{204} \mathrm{~Pb}$ was corrected using the measured signal intensity of ${ }^{202} \mathrm{Hg}$, 343 and the abundance ratio ${ }^{202} \mathrm{Hg} /{ }^{204} \mathrm{Hg}$ equaled 4.35 . Special attention was paid by measuring 344 the additional ${ }^{201} \mathrm{Hg}$, yielding the ratio of signal intensity of both isotopes with respect to the 345 abundance ratio ${ }^{202} \mathrm{Hg} /{ }^{201} \mathrm{Hg}$ and showing evidence of spectral interference free $\mathrm{Hg}$ isotopes. 346 The $\mathrm{Pb}$ isotope ratios $\left({ }^{204} \mathrm{~Pb} /{ }^{206} \mathrm{~Pb},{ }^{207} \mathrm{~Pb} /{ }^{206} \mathrm{~Pb},{ }^{208} \mathrm{~Pb} /{ }^{206} \mathrm{~Pb}\right)$ were corrected for instrumental 347 mass discrimination using the exponential law (Fig. S13). The mass bias factor applied to the 348 five replicate analyses of an unknown sample is the average of such factors calculated from 349 analyses of the NIST SRM981 Pb both before and after the sample analyses. The errors 350 calculated on $\mathrm{Pb}$ isotope ratios in soil samples correspond to two standard deviations from 351 the mean $(2 \sigma)$ based on five replicate analyses of the same sample solution.

\subsubsection{Tree sample preparation and $U$ HR-ICP-MS analysis}

353 Individual rings were cut out using a sterilized scalpel that was washed with high purity ethanol and $5 \% \mathrm{HNO}_{3}(\mathrm{v} / \mathrm{v})$; this step was followed by a Milli-Q wash in between cuts. The obtained sample weights varied from 10 to $40 \mathrm{mg}$. The digestion procedure has been samples. The wood sections were washed in $0.1 \mathrm{M} \mathrm{HNO}_{3}$ for about an hour and then dried in an oven for $7 \mathrm{~h}$ at $70^{\circ} \mathrm{C}$ (until achieving constant weight). Next, the samples were weighed 359 and deposited in a 5-mL Savillex container, with $1 \mathrm{~mL}$ of concentrated $\mathrm{HNO}_{3}$ being added. 360 The containers were placed in an oven at $80^{\circ} \mathrm{C}$ for one day; $0.5 \mathrm{~mL}$ of ultrapure $30 \% \mathrm{H}_{2} \mathrm{O}_{2}$ 361 were added and the samples placed back in the oven for one more day. The solutions were 362 then cooled and diluted in $2 \% \mathrm{HNO}_{3}(\mathrm{v} / \mathrm{v})$ using the ${ }^{205} \mathrm{TI}$ internal standard working solution 
363 prepared at a concentration of $50 \mathrm{ng} \cdot \mathrm{L}^{-1}$. The suitability and accuracy of this method were 364 tested through a digested standard reference material, i.e. SRM NIST 1570a spinach leaves 365 ( $U$ content $=0.155 \pm 0.023 \mathrm{mg} \cdot \mathrm{kg}^{-1}$ ) according to the same procedure.

366 The $U$ concentrations in tree ring sample solutions obtained after digestion were measured 367 by means of the HR-ICP-MS. The optimized ICP-MS operating conditions are given in Table 368 S12. The calibrated $U$ standards were prepared from $1,000 \mathrm{mg} \cdot \mathrm{L}^{-1}$ uranium ICP standard 369 solution (SCP Science). Typical standard calibration curves could be obtained from 370 measurements of the $2 \% \mathrm{HNO}_{3}(\mathrm{v} / \mathrm{v})$ blank solution and $\mathrm{U}$ standard solutions of $10,20,30$ 371 and $50 \mathrm{ng} \cdot \mathrm{L}^{-1}$. The correlation coefficient $\left(\mathrm{R}^{2}\right)$ values over the study duration were between 3720.999 and $1.00 .{ }^{205} \mathrm{TI}$ and ${ }^{238} \mathrm{U}$ were measured at low resolution in E-scan acquisition mode, 373 with the detector in triple mode. The limits of detection ranged from 0.002 to $0.2 \mathrm{ng} \cdot \mathrm{kg}^{-1}$, 374 and the relative standard deviation $(2 \sigma)$ was $<15 \%$. 
375 4. Results

376

377

378

379

380

381

382

383

384

385

386

387

388

389

390

391

392

393

394

395

\subsection{Records and maps}

\subsubsection{Records}

Given this setting where mining operations previously encompassed the entire Gourgeat watershed, further details into what actually happens during mining can be gleaned from a study of several records. From selected correspondence, a description of the extracted minerals and residue could be clarified. Some ore bodies contain kaolinite clays, which were detrimental to the ore washing plant process during the sedimentation step and resulted in a loss of $U$ mineral particles with mine tailings (Table S14, 29/06/1948). The discharge waters into the Gourgeat stream after the settling ponds were turbid due to an excess capacity limitation and inadequate maintenance of the facility (i.e. a mix of mud and sand never emptied) (Table S14, 27/10/1950, 21/04/1952, 20/10/1952, 27/07/1953, 26/06/1954). From these letters (Table S14, 12/01/1951, 27/07/1953 and 26/06/1954), we learned that a white coloration of the Terrasson and Vauziron streams over a distance of several kilometers was reported due to fine particles clogging the filters for the abstraction of drinking water to supply the City of Chateldon.

\subsubsection{Maps}

A study of the 9 available prior aerial photographs from 1946 to 2015 (Fig. S6) has highlighted the changes induced by mining activities on the watershed as regards the timeline events (Fig. 1). Before the mine was founded in 1946, the head of the watershed was a grassland dedicated to breeding with a small stream running through the center. On the 1954 photograph showing mining operations, the footprint of mine installations with settling ponds is clearly visible. A large white deposit in the watershed some $200 \mathrm{~m}$ 
398

399

400

401

402

403

404

405

downstream of the hydraulic output of the Rophin settling ponds can be noticed. Moreover, the small stream is highlighted by a white color, in comparison with the photographs from 1946. The mine was then abandoned and overrun by vegetation (Fig. S6, 1960 and 1974).

The first site rehabilitation is visible on the 1983 picture, with a large forest clearing on the mine for the purpose of dismantling the former installations. This step was repeated (visible in the 2004 photo) for the erection of a fence in 2015 in order to secure the ICPE installation. Since 1960, the vegetation growing in the watershed downstream of the mine has now become forestland.

\subsection{Gamma survey results}

Results from the gamma survey are reported in Fig. 2 as a gamma cartography with 3 radioactivity levels. The measured gamma dose rates range from 80 to $1,050 \mathrm{nSv} \cdot \mathrm{h}^{-1}$ in following a Gaussian distribution pattern for values between 80 and 350 nSv. $\mathrm{h}^{-1}$. Regarding the wider area under investigation, this pattern was assumed to be the local geological background (GB) of the Rophin area, with a mean value of $210 \mathrm{nSv} \cdot \mathrm{h}^{-1}$, which aligns with a regional background between 201 and 250 nSv.h-1 measured by IRSN, (2014). From this initial observation, two additional radioactivity levels were defined as 1-2 times and 2-4 times the geological background (i.e. 350-700 and 700-1,400 nSv. ${ }^{-1}$ ) in order to facilitate the reading of interpolated results on the gamma cartography.

The northern part of the ICPE area and the two creeks running from the north, which supply water to the wetland area, show values around the level of the GB. In the eastern part of the map, from the effluent waters discharged by the ICPE, a level of 1-2 GB was measured. The gamma radiation level then increases to $1-4 \mathrm{~GB}$ (maximum at 1,050 nSv. $\mathrm{h}^{-1}$ ) in the watershed after the confluence of the Gourgeat creek from the north and ICPE effluent waters (Fig. 2). 
421 This high gamma dose rate level was localized on the valley floor, characteristic of a wetland,

422 along the stream within a wide surrounding area without any clear pattern for maximum

423 values. This gamma survey served as the basis for implementing the soil sampling strategy.

\subsection{Soil analysis}

\subsubsection{Soil properties}

426 The U1 soil core was sampled in the upstream grassland, whereas D1 and D2 were sampled 427 in a wooded wetland fully saturated by water during a high flow period (Fig. 2). 428 Consequently, these soil layers were considered at their maximum water holding capacity.

429 By observation of the D1 core (Fig. 2 and Fig. 3), 4 layers can be distinguished, based on 430 visual criteria and soil organic matter (SOM) content. The top of the core $(\mathrm{D} 1-1 ; 0-18 \mathrm{~cm})$ 431 consists of black soil composed of fibrous material and roots with a very high water content 432 (78\% of total mass) and SOM (34\% of dry mass). At a depth between 18 and $30 \mathrm{~cm}$ (D1-2), 433 the soil layer features a whitish color with a silt loam texture, a low organic content (8\%) and 434 a water content dropping to minimum value of $26 \%$. The next layer $(D 1-3 ; 30-70 \mathrm{~cm})$ is 435 characterized by a brown color and a high organic carbon content (45\%), which suggests a 436 more heavily decomposed organic matter than in the D1-1 layer. The last brown-gray soil 437 layer (D1-4; 70-100 cm) comprises a mix of organic and mineral characteristics, with a low 438 level of SOM (7\%), an apparent silt loam texture and a decreasing water content with depth 439 (from 83\% to 18\%). The water and SOM contents of core D2 at the centimeter scale (Fig. 4) 440 corroborate the differences between the first 3 layers as well as the correlation between 441 SOM and water, i.e. the higher the content of water, the higher the content of SOM. Layers 442 D1-2 and D2-2, displaying the same characteristics, will be referenced as the WSL (whitish 
443 silt loam) layer. Note that this particular WSL layer was not observed in the U1 soil core (Fig. $4442)$.

445

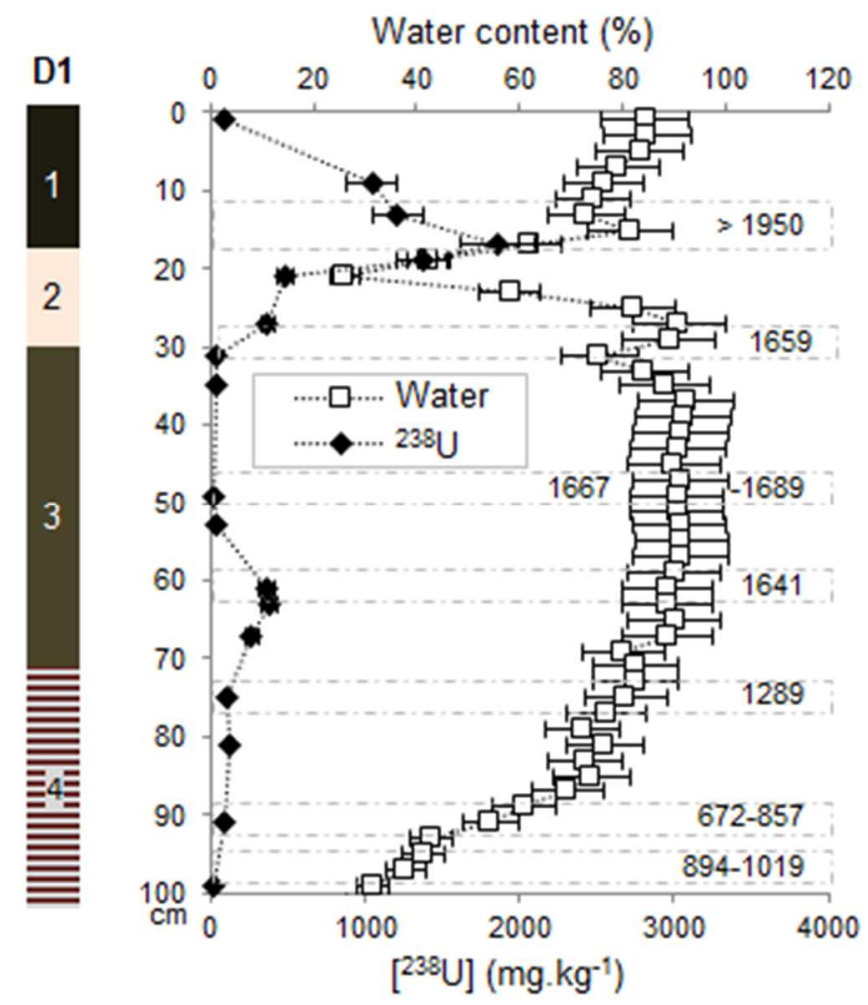

446 Fig. 3: Simplified soil profile description of core D1 $(100 \mathrm{~cm})$ with water content, ${ }^{238} \mathrm{U}$ concentrations 447 in dry mass and with ${ }^{14} \mathrm{C}$ dating.

\subsubsection{Uranium depth profiles and distribution in the watershed}

449 The $U$ concentrations determined range from 8.9 to $3,560 \mathrm{mg} \cdot \mathrm{kg}^{-1}$ in dry mass for cores D1 450 and D2 (Fig. 3 and Fig. 4). An analysis of the $U$ soil profile for the D1 core reveals a $U$ 451 concentration increase between the D1-1 and D1-2 layers $(10-20 \mathrm{~cm})$ for the highest 452 concentration (i.e. $1,855 \mathrm{mg} \cdot \mathrm{kg}^{-1}$ ) and a smaller rise at the end of the D1-3 layer (379 mg.kg-

$45{ }^{1}$ ). The D1-4 layer exhibits a low $U$ concentration of around $10 \mathrm{mg} \cdot \mathrm{kg}^{-1}$, which is in agreement 454 with the local geological background (11-59 mg.kg-1, from (Salpeteur and Angel, 2010)). 455 Layers D1-3 and D1-4 can thus be considered as the soil reference before the period of 456 mining operations. The higher spatial resolution of core D2 over $30 \mathrm{~cm}$ highlights two $U$ 
peaks at the interface between D2-1/2, in accordance with D1 results, and in the lower part

458

459

460

461 at the interface with the topsoil layers (D1-1 and D2-1) characterized by a high SOM content.

462

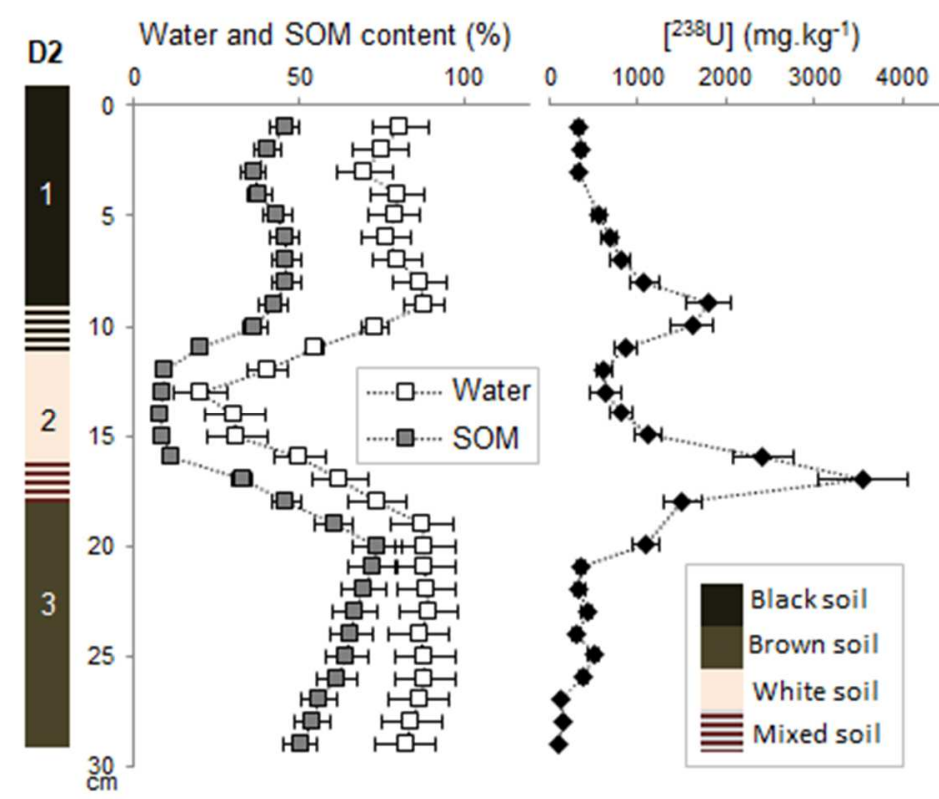

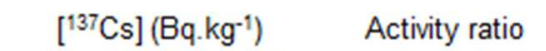

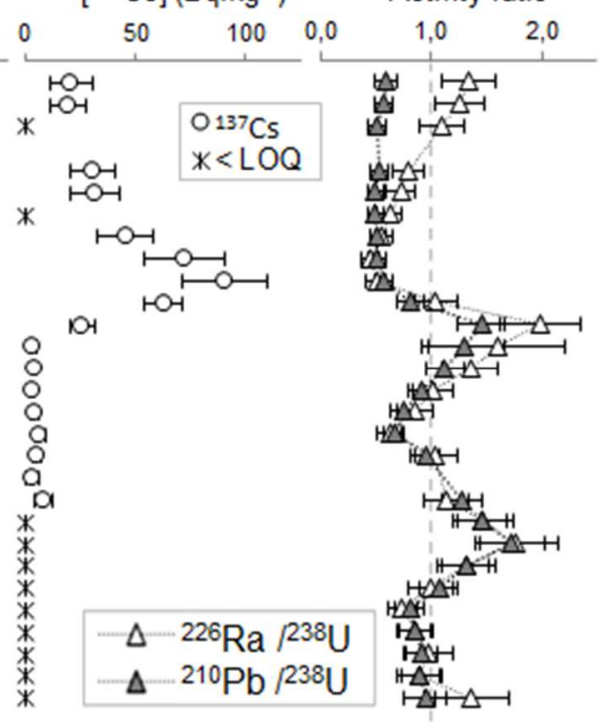

of D2-2 (not visible on D1 results), with respective intensities of $1,800 \mathrm{mg} \cdot \mathrm{kg}^{-1}$ and 3,560 mg. $\mathrm{kg}^{-1}$. By considering the density and water content of each soil layer, the highest mass of $\mathrm{U}$ is primarily stored in the WSL layer (D1-2 and D2-2), with a tendency to accumulate locally
463

464

465

466

467

468

469

470

471

Fig. 4: Simplified soil profile description of core D2 $(30 \mathrm{~cm})$ with water and SOM contents, ${ }^{238} \mathrm{U}$ concentrations in dry mass, ${ }^{137} \mathrm{Cs}$ activity in dry mass (LOQ : Limit of Quantification) and activity ratios of ${ }^{226} \mathrm{Ra}$ and ${ }^{210} \mathrm{~Pb}$ to ${ }^{238} \mathrm{U}$.

This correlation between $U$ stock and WSL layer was confirmed by the M-series of $50-\mathrm{cm}$ cores in the area (Fig. S9), which also indicated the presence of the WSL layer, mainly in the center of the watershed downstream of the mine discharge location. Moreover, the $U$ soil profile concentrations of the $\mathrm{U} 1$ core (not shown here) reveal a single increase in $\mathrm{U}$ concentration, from 51 to $77 \mathrm{mg} \cdot \mathrm{kg}^{-1}$, in the organic topsoil layer $(0-7 \mathrm{~cm})$; this result is consistent with the absence of the characteristic WSL layer in the first $30 \mathrm{~cm}$.

472 The measured $\left({ }^{226} \mathrm{Ra} /{ }^{238} \mathrm{U}\right)$ and $\left({ }^{210} \mathrm{~Pb} /{ }^{238} \mathrm{U}\right)$ activity ratios range from 0.46 to 2.00 and from 4730.50 to 1.73 , respectively (Fig. 4). Due to the highly distinct mobility of the "long-life" 
474 radionuclides of the ${ }^{238} \mathrm{U}$ decay chain $\left({ }^{238} \mathrm{U},{ }^{226} \mathrm{Ra}\right.$ and $\left.{ }^{210} \mathrm{~Pb}\right)$, an activity ratio close to the 475 secular equilibrium highlights a collective transport of radionuclides mainly in particle form 476 (Zielinski et al., 1986), whereas a deviation stands out for an output (by migration) or input 477 (of various origins) of one radionuclide from the decay chain. The ratio value close to 1 at the 478 end of D2-3 is in line with a natural $U$ geological background in secular equilibrium. If we 479 look closely at the results, the second $U$ peak in the lower part of D2-2 correlates with a ratio 480 close to 1 , thus suggesting past transport in particulate form. However, an excess of ${ }^{226} \mathrm{Ra}$ 481 and ${ }^{210} \mathrm{~Pb}$ observed in the middle of the WSL layer could suggest a depletion in U. The D2-1 482 layer with the first $U$ peak shows a continuous deviation from 0.46 at $10 \mathrm{~cm}$ to 1.34 at the 483 soil surface for the ${ }^{226} \mathrm{Ra} /{ }^{238} \mathrm{U}$ ratio, in comparison with the ${ }^{210} \mathrm{~Pb} /{ }^{238} \mathrm{U}$ ratio of around 0.5 . 484 This difference in behavior combined with the deviation from a ratio of 1 signifies a rupture 485 in the decay chain between ${ }^{226} \mathrm{Ra}$ and ${ }^{210} \mathrm{~Pb}$ and a non-equilibrium with ${ }^{238} \mathrm{U}$. The ${ }^{226} \mathrm{Ra} /{ }^{238} \mathrm{U}<$ 4861 , at the end of the D2-1 layer, may highlight the input of ${ }^{238} \mathrm{U}$ into this soil layer by means of 487 a vertical migration from the WSL layer (D2-2).

488 In addition, SEM has revealed the presence of a large number of U-rich particles with 489 diameters between 1 and $20 \mu \mathrm{m}$ in the D2-1 and D2-2 layers of the core (Fig. S6). The EDS 490 spectra show the presence of $U$ at contents as high as $50 \%$ and an association with other 491 elements (Pb, Fe, Cu. Al, Si and O).

\subsubsection{Tracers: ${ }^{14} \mathrm{C},{ }^{137} \mathrm{Cs}$ and stable lead isotopy}

$493{ }^{14} \mathrm{C}$ dating results on core D1, as detailed in Table S11 and summarized in Fig. 3, show a post4941950 age for the depths $12-14$ and $16-18 \mathrm{~cm}$. The sample at depths of $20-22 \mathrm{~cm}$ (aliquoted in 495 WSL) could not be dated by the ${ }^{14} \mathrm{C}$ dating technique since it was devoid of carbon. From 30 
to $100 \mathrm{~cm}$, older ages of up to 1 millennium are involved. The dating step has been refined

497 over the first $30 \mathrm{~cm}$ via ${ }^{137} \mathrm{Cs}$ on core D2 (Fig. 4).

498 Cesium makes it possible to date sediments by their ${ }^{137} \mathrm{Cs}$ activity caused by nuclear fallout 499 (IAEA, 1998, p.6) combined with their limited mobility properties. The specific ${ }^{137} \mathrm{Cs}$ activity in 500 the D2-1 layer reaches an intermediate value of $31.7 \mathrm{~Bq} \cdot \mathrm{kg}^{-1}$ at $6 \mathrm{~cm}$, and a maximum of 91 501 Bq. $\mathrm{kg}^{-1}$ was observed right at the D2-1/2 interface (Fig. 4). The values then decrease to 502 roughly $3.4 \mathrm{~Bq} \cdot \mathrm{kg}^{-1}$ for the lower parts of the D2-2 and D2-3 layers. Below $20 \mathrm{~cm}$, the values 503 were less than the limit of detection. Since the main peak of ${ }^{137} \mathrm{Cs}$ activity in the D2 core is 504 located directly above the WSL layer and only very low values were detected below, it seems 505 safe to assume that this layer was deposited before the peak in nuclear weapons testing at 506 the beginning of the 1960's (IAEA, 1998, p.45). Moreover, this finding is consistent with ${ }^{14} \mathrm{C}$ 507 dating for this layer (post-1950 age).

508 The benefit of using stable lead isotopes (Fig. 5) is to both highlight the existence of an 509 environmental marker related to the presence of $U$ and discriminate between anthropogenic 510 (uranium stemming from mining and milling activities) and natural input (uranium from the 511 geochemical background). Most stable $\mathrm{Pb}$ isotopes are indeed present in the decay chains of 512 naturally occurring radionuclides $\left({ }^{238} \mathrm{U} \rightarrow{ }^{206} \mathrm{~Pb},{ }^{235} \mathrm{U} \rightarrow{ }^{207} \mathrm{~Pb}\right.$ and $\left.{ }^{232} \mathrm{Th} \rightarrow{ }^{208} \mathrm{~Pb}\right)$ and 513 moreover ${ }^{204} \mathrm{~Pb}$ is non-radiogenic.

514 Our data are shown in a three-isotope diagram $\left({ }^{207} \mathrm{~Pb} /{ }^{206} \mathrm{~Pb}\right.$ vs. ${ }^{204} \mathrm{~Pb} /{ }^{206} \mathrm{~Pb}$, Fig. $\left.5 \mathrm{a}\right)$, thus 515 showcasing the mixing processes between various pollution sources. For purposes of 516 comparison, the A64 sample (Loire surface sediment 47²17'17" $\mathrm{N}-02^{\circ} 10^{\prime} 54^{\prime \prime} \mathrm{W}$ (Péron et al., 517 2016), which is not under the influence of mining discharges) was used as the geochemical 518 background end-member with a ${ }^{207} \mathrm{~Pb} /{ }^{206} \mathrm{~Pb}$ ratio $(0.859 \pm 0.001)$ close to the Present Day 
519 Average Crustal (PDAC) ${ }^{207} \mathrm{~Pb} /{ }^{206} \mathrm{~Pb}$ ratio estimated at 0.83 (Cumming and Richards, 1975;

520 Stacey and Kramers, 1975). As observed in Figure 4a, the alignment of the samples $\left(R^{2}=\right.$ 521 0.9999) confirms a binary mixing between the U-ore particles and the geochemical 522 background. This outcome clearly highlights an anthropogenic signature in the recent core 523 layers, in comparison with the PDAC and A64, which are consistent with a post-mining 524 context. In order to calculate the radiogenic $\mathrm{Pb}$ contribution in the core samples, a precise 525 determination of the $\mathrm{Pb}$ end-members is of great importance. The A64 sample was used for 526 the geochemical background end-member and for the intercept of the linear regression in 527 Figure $4 \mathrm{a}$ as the ${ }^{207} \mathrm{~Pb} /{ }^{206} \mathrm{~Pb}$ radiogenic end-member. By applying the mixing model and 528 taking the $\mathrm{Pb}$ atomic abundances into account, it is possible to correctly calculate the 529 contribution of radiogenic lead ( $k$, in \%) to the total lead for each sample (Gourgiotis et al., 530 2020).

531 The 6 soil samples at a depth below $30 \mathrm{~cm}$ (D1-3 and D1-4 layers) present similar ${ }^{207} \mathrm{~Pb} /{ }^{206} \mathrm{~Pb}$ 532 ratio values, ranging from $0.7664 \pm 0.0009$ to $0.808 \pm 0.001$, with $1.4 \pm 0.07 \%<k<1.7 \pm$ $533 \quad 0.07 \%$ corresponding to a slight $U$ enrichment signature. The soil samples at $12-14 \mathrm{~cm}$ (D1-1) 534 and $20-22 \mathrm{~cm}$ (top of D1-2) display an intermediate value for both ratios and $k=3 \pm 0.07 \%$ 535 and $k=2.7 \pm 0.08 \%$, respectively. However, the lowest ${ }^{207} \mathrm{~Pb} /{ }^{206} \mathrm{~Pb}$ and ${ }^{204} \mathrm{~Pb} /{ }^{206} \mathrm{~Pb}$ ratios 536 were found for the $16-18 \mathrm{~cm}$ sample with values of respectively $0.6378 \pm 0.0005$ and $5370.04007 \pm 0.00005$. This sample, with $k=8.6 \pm 0.07 \%$, is located at the interface between the 538 D1-1 and D1-2 layers in the highest contaminated zone of core D1 ([U] $]_{\text {soil }}$ between 1,210 and $\left.5391,850 \mathrm{mg} \cdot \mathrm{kg}^{-1}\right)$. These results are in agreement with the ${ }^{207} \mathrm{~Pb} /{ }^{206} \mathrm{~Pb}$ ratios obtained for $\mathrm{U}$ 540 contaminated soils and isotopic background in (Cuvier et al., 2016), at 0.6578 and 0.8305 , 541 respectively. 
a)

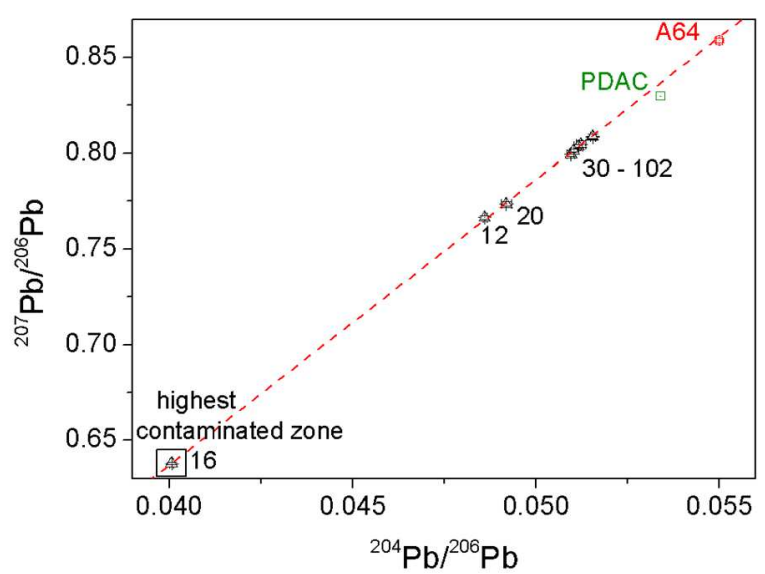

b)

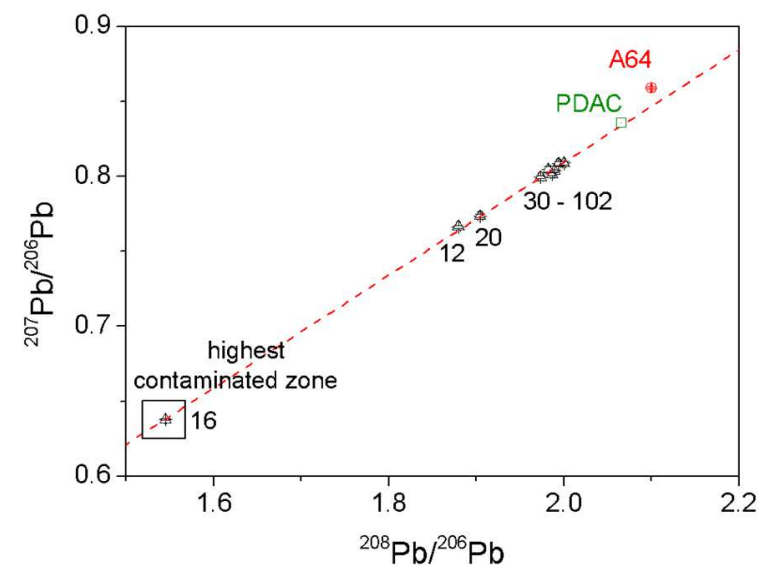

543

544

545

546

547

548

549

550

551

552

553

554

555

556

557

558

559

Fig. 5: a) ${ }^{207} \mathrm{~Pb} /{ }^{206} \mathrm{~Pb}$ vs. ${ }^{204} \mathrm{~Pb} /{ }^{206} \mathrm{~Pb}$ isotope ratios, and b) ${ }^{207} \mathrm{~Pb} /{ }^{206} \mathrm{~Pb}$ vs. ${ }^{208} \mathrm{~Pb} /{ }^{206} \mathrm{~Pb}$ isotope ratios of core D1. In addition, A64, Loire Surface sediment and PDAC (Present Day Average Crustal Ratios) (Cumming and Richards, 1975; Stacey and Kramers, 1975) have been plotted. The dashed line represents the linear regression. The uncertainties $(2 \sigma)$ are included in the plot. The values indicated under the points correspond to the depths (in $\mathrm{cm}$ ). The 30-102 $\mathrm{cm}$ range includes 6 sampling depths, namely 30, 48, 60, 74, 90 and $102 \mathrm{~cm}$.

The ${ }^{207} \mathrm{~Pb} /{ }^{206} \mathrm{~Pb}$ vs ${ }^{208} \mathrm{~Pb} /{ }^{206} \mathrm{~Pb}$ plot (Fig. 5b) confirms the presence of environmental contamination, mainly due to the presence of $U$-bearing phases from the $U$ mine, which underscores the absence of thorogenic ${ }^{208} \mathrm{~Pb}$ in the $\mathrm{U}$-ore. This observation is consistent with the U-ore minerals of Rophin previously described, which are lacking in ${ }^{232} \mathrm{Th}$. The linear regression $\left(R^{2}=0.9996\right)$ indeed indicates binary mixing with no supply of ${ }^{208} \mathrm{~Pb}$ in the highest contaminated zone. The highest contaminated zone $(16-18 \mathrm{~cm}$ sample) has the lowest ${ }^{208} \mathrm{~Pb} /{ }^{206} \mathrm{~Pb}$ ratio: $1.5451 \pm 0.0009$. In a post- $\mathrm{U}$ mining context, the results are consistent $\left({ }^{238} \mathrm{U}\right.$ to $\left.{ }^{206} \mathrm{~Pb}\right)$ with the geochemical background $\mathrm{A64}{ }^{208} \mathrm{~Pb} /{ }^{206} \mathrm{~Pb}$ ratio: $2.100 \pm 0.001$. These results are also in agreement with the isotopic background $\left({ }^{208} \mathrm{~Pb} /{ }^{206} \mathrm{~Pb}=2.09\right)$ and $\mathrm{U}$ contaminated soils $\left({ }^{208} \mathrm{~Pb} /{ }^{206} \mathrm{~Pb}=1.620\right)$ obtained in (Cuvier et al., 2016). The ${ }^{208} \mathrm{~Pb} /{ }^{206} \mathrm{~Pb}$ ratio indicates that the enrichment matches with an uranogenic and not thorogenic $\mathrm{Pb}$. The 
561 other depths, which correspond to a slight $U$ enrichment signature, present intermediate $562{ }^{208} \mathrm{~Pb} /{ }^{206} \mathrm{~Pb}$ ratio values ranging from $1.8795 \pm 0.0009$ to $2.000 \pm 0.001$.

\section{4. $\quad$ Tree ring analysis}

564 Uranium concentrations measured in the tree rings by HR-ICP-MS are given in Fig. 6;

565 concentrations were detected and quantified in all tree rings analyzed. The distribution 566 patterns of these tree samples reveal different trends.
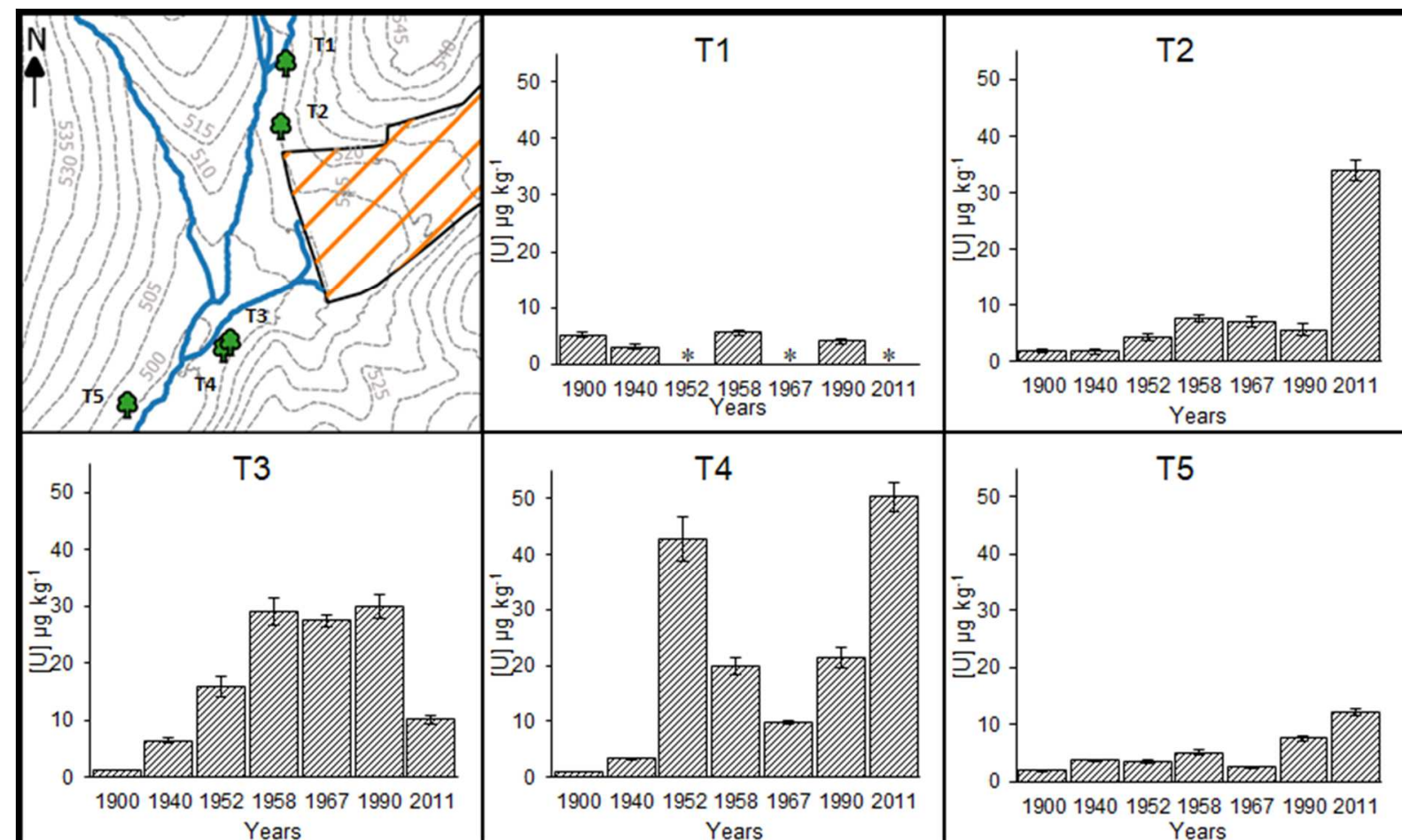

Fig. 6: Locations of the oak trees with contour lines in the Gourgeat watershed (upper left) and

570 For T5, located far from the former mine without any apparent connection to the watershed

571 due to an elevation difference (Fig. 6), $U$ values ranging from 2 to $12 \mu \mathrm{g} . \mathrm{kg}^{-1}$ were obtained

572 (with low variations over time). For the upstream trees, T1 and T2, $\mathrm{U}$ concentrations did not

573 increase over time or only very slightly (except T2 in 2011). The $U$ concentrations found for

574 T1 and T2 during the various years analyzed are of the same order of magnitude, i.e. ranging 
575 from 2 to $7 \mu \mathrm{g} \cdot \mathrm{kg}^{-1}$ and up to $34 \mu \mathrm{g} \cdot \mathrm{kg}^{-1}$ for T2 in 2011. The values for trees T3 and T4,

576 located downstream of the storage site, fluctuate strongly over time, from 1 to $50 \mu \mathrm{g} . \mathrm{kg}^{-1}$

577 with two distinct temporal trends. For T3, the concentration gradually increases until 1990

578 and declines for 2011. For T4, after a maximum concentration measured in 1952, the

579 concentration decreases until 1967 and starts increasing again in 2011.

580 Knowing that the mine was discovered in 1924, the low $U$ concentration values for the year

5811900 (ranging from 1 to $5 \mu \mathrm{g} \cdot \mathrm{kg}^{-1}$ ) are expected to represent the local tree ring background.

582 These backgrounds however are higher than other values given in the literature for oak trees

583 (between 0.3 and $1 \mu \mathrm{g} . \mathrm{kg}^{-1}$ ) (Edmands et al., 2001; Monticelli et al., 2009). This finding may

584 be explained by the naturally increasing $U$ levels in the soil $\left(10 \mathrm{mg} \cdot \mathrm{kg}^{-1}\right)$ of areas with granitic 585 bedrock, especially near $U$ deposits.

586 5. Discussion

587 A data integration approach is proposed in this section in order to offer insight into what has 588 actually happened in the Gourgeat watershed. The gamma survey results indicate a 589 contamination in the Gourgeat watershed downstream of the ICPE facility, in contrast with 590 the upstream of the watershed. This finding has been confirmed by the high $U$ 591 concentrations measured in the topsoil $(<30 \mathrm{~cm})$ of cores D1, D2 and the $M$ series. More 592 specifically, the highest $U$ concentrations measured in the soil profiles of cores D1 and D2 593 were localized around the WSL layer (D1-2 and D2-2); this layer with a specific texture, a low 594 water and organic matter content and a high $U$ content was not observed in the U1 core. 595 Such an observation has led to the hypothesis that this contaminated WSL soil layer 596 originated from a natural source or anthropogenic activities located near the current ICPE 597 site. The overlap of gamma survey results with the 1954 aerial photograph (Fig. 2) shows a 
partial correlation with a large white surface deposit, visible in the watershed around $200 \mathrm{~m}$

599 downstream of the hydraulic output of the former Rophin settling ponds (deposit not 600 observable in 1946, see Fig. S6). The hypothetical contamination scenario can therefore be 601 refined to a diffuse distribution of natural radionuclides from mine operations transported 602 by water. In other words, the WSL layer could have been deposited in the wetland during a 603 flooding event or else by slow sedimentation as a covering layer of mining materials. This 604 scenario is supported by evidence in the records of: i) ore bodies containing kaolinitic clays 605 (fine particles), ii) malfunction and inadequate maintenance of the settling ponds, and iii) 606 turbid waters with a white coloration in the Gourgeat, Terrasson and Vauziron streams. 607 Moreover, the dating of soil cores D1 and D2 by ${ }^{14} \mathrm{C}$ and ${ }^{137} \mathrm{Cs}$ corroborates the deposit of the 608 WSL post-1950 (for ${ }^{14} \mathrm{C}$ ) and before the beginning of the 1960 's (for ${ }^{137} \mathrm{Cs}$ ), which is in 609 agreement with the timeline (Fig. 1) and the end of mining activities in 1957. In addition, 610 lead isotope ratios indicate that contamination at a depth below $30 \mathrm{~cm}$ is slightly influenced 611 by U-mine material (compared to PDCA and A64), while contamination at around $12-22 \mathrm{~cm}$ 612 can be distinguished between intermediate and high enrichment signatures with a greater 613 contribution of radiogenic lead to total lead $(k=8.6 \pm 0.07 \%)$ at $16 \mathrm{~cm}$. Similarly, the 614 enrichment factors, calculated from the mean geochemical background in the D1-3 and D1-4 615 layers dated prior to $1700\left([\mathrm{U}]_{\mathrm{GB}}\right.$, soil $\left.=101 \mu \mathrm{g} \cdot \mathrm{kg}^{-1}\right)$, range from 3.7 to 35.4 in the WSL layer 616 and from 0.9 to 18.4 in topsoil layers. The WSL layer may thus be used in future studies as a 617 visual tracer during field sampling and as an indicator of a mining activity footprint. 618 Combining this $\mathrm{U}$ marking of the wetland with the ${ }^{14} \mathrm{C}$ dating technique, it can be assumed 619 that the wetland is an accumulation area for natural $U$ and its radioactive daughter for up to 6201,000 years. This information clearly demonstrates the recent impact of anthropic mining 621 activities not only in the WSL layer but in topsoil layers as well. Following this assessment, 
some questions arise, regarding for example the form of transport, and the migration

623 behavior and bioavailability of the radionuclides. The means of transporting radionuclides by

624 turbid waters in the watershed suggests migration in particulate form and most likely as ore

625 particles given the poor efficiency of the ore washing plant process being applied (mainly

626 parsonsite in 1949-1954 and pitchblende in 1955-1957). The measured ratios of the activities

627 of ${ }^{238} \mathrm{U}$ to ${ }^{226} \mathrm{Ra}$ and ${ }^{210} \mathrm{~Pb}$ for the $\mathrm{U}$ second peak in the lower part of the $\mathrm{D} 2-2$ layer (Fig. 4)

628 correlates with a ratio value close to 1 , which confirms partial transport as non-altered ore

629 particles. Moreover, SEM (Fig. S8) revealed the existence of U-rich particles in this layer, but

630 the stoichiometry determined by EDS cannot be confirmed with the ore composition of

631 parsonsite or pitchblende. It is therefore assumed that at least a portion of the deposited $U$

632 mineral particles have dissolved over time. However, disequilibrium in the decay chain for

633 the topsoil layer (D2-1) might suggest an enrichment of $U$ by the migration of $U$ as aqueous

634 species and sorption on SOM. Two hypothesis can be formulated: i) a slow dissolution of $U$

635 particles contained in the WSL layers over decades, followed by an accumulation in the

636 topsoil layer associated with a seasonal change of water level in the wetland; or ii) a regular

637 inflow over the decades of $U$ dissolved by water from the Gourgeat creek altered by mine

638 water effluent even after ICPE site rehabilitations. Such an accumulation mechanism in the

639 wetland has been detected and similarly described for other sites affected by $U$ mining

640 (Bister et al., 2015; Mangeret et al., 2018). At the same time, the fact that $U$ concentrations

641 quickly decrease below the WSL in cores D1 and D2 suggests that the mobility of the $U$

642 deposited by diffusion has been rather low under the conditions prevailing during the last 50

643 years. In conclusion, the wetland, enriched in SOM, acts as a radionuclide trap for natural or

644 anthropogenic $U$ emissions observed at the Rophin site over the decades. 
645 In this study, the dendroanalysis has served to correlate the $U$ emissions from Rophin with

646 the site history using oak tree rings as a suitable bioindicator of changes in bioavailable $U$

647 concentrations. Considering the local tree ring background observed in 1900, two $U$ 648 concentration variations between 1940 and 2011 can be concluded. First, the maximum U 649 values were observed between 1949 and 1958 for the T3 and T4 trees. This increase in U 650 concentration in tree rings coincides with the period of mining activities (1949-1957) with an 651 extended period of influence for T3. This result confirms the past transport of $U$ into the 652 hydraulic system in a bioavailable form. Moreover, by comparing $U$ concentrations in the 653 tree rings of T5 (no hydraulic influence) and T1 and T2 (located upstream) with the T3 and T4 654 results (located downstream of the former mine and near the effluent waters) for this same 655 period, it is reasonable to assume that this increase could be attributed to mining 656 operations. Such anthropogenic activities could have generated bioavailable $U$ 657 concentrations, via the documented effluent waters and/or particle deposits (WSL layer), 658 accumulated by the roots of trees growing in the wetland. Let's note that $U$ concentrations 659 in tree rings did not return to the local background level even after mining operations ceased 660 (in 1958). Although an influence on T3 and T4 trees is observed, the concentrations 661 identified are still very low compared to those obtained by Märten et al., (2015) (around 400 $662 \mu \mathrm{g} \cdot \mathrm{kg}^{-1}$ for the maximum $\mathrm{U}$ concentration). This difference is probably due to both the length 663 of time the site had been in operation (including the processing period) and the quantity of 664 ore extracted. The Rophin site was in fact only operated for 8 years (vs 40 years for "Reuster 665 Forst"), including one year of shutdown (in 1951) for economic reasons. This "short" 666 operating period has certainly helped mitigate the impact of these mining activities on plants 667 growing in this region. Second, a large increase in $U$ concentration (more than 20 times the 668 background level) was observed in 2011 for trees T2 and T4. This trend is also slightly visible 
669 for the non-influenced T5 tree (6 times). This particular period coincides with the major soil

670 transformations of the Rophin site in 2002 and 2010 (Fig. 1 and Fig. S3), which are visible on

671 the aerial photographs from 1993 to 2015 (Fig. S6). Since the variation was observed on both

672 upstream (T2) and downstream (T4) trees in the vicinity of the ICPE site (and slightly on T5

673 located further away), the hypothesis of an atmospheric contamination during the

674 transformation is indeed possible. The transfer of elements within tree rings is a complex

675 process that depends on a variety of parameters, such as soil $\mathrm{pH}$, soil organic matter,

676 bioavailability, concentrations in the environment, and the uptake capacity of trees (Cutter

677 and Guyette, 1993). Atmospheric contamination during mining is thus one of the pathways

678 of metal transport into trees (Lepp, 1975; Sansone et al., 2001). This determination

679 corresponds mainly to foliar uptake, with subsequent export from the leaf via the phloem,

680 followed by a lateral movement from this tissue into the xylem. However, the relationship

681 between these levels of deposition and the levels in leaves and in other plant parts is

682 presently unknown. On the other hand, this hypothesis is counterbalanced by the T3 tree

683 results, which showed a higher U concentration in 1990 than in 2011.

684 Thanks to our methodology, which employs an integrated approach with a study of records,

685 a gamma survey, and soil and tree ring analyses, it has been possible to trace the 686 contamination history at the Rophin site. Beyond the interest in this methodology, the 687 results of this work will provide the basis for future projects taking place in a ZATU workshop 688 context. Further studies are being planned to better understand the processes taking place 689 in the soil layers in order to derive predictions of the overall dynamics occurring at the site. 
691 6. Acknowledgments

692 The authors are grateful to the ZATU Pilot Workshop within the Hercynian orogeny (ZATU,

693 https://zatu.org/), with the "Nantes-Atlantique Universe Sciences Observatory" (OSUNA,

694 https://osuna.univ-nantes.fr/). The present study has been financially supported by the 695 POLLUSOLS program (OSUNA) and co-financed by the Loire Valley (Pays de la Loire) Regional 696 Council.

697 Thanks are also extended to Stephan Weiss with the Helmholtz-Zentrum Dresden698 Rossendorf, Institute of Resource Ecology, and Guillaume Blain with Subatech for his 699 practical advice concerning the sampling procedure, as well as to Catherine Landesman, 700 Fengqi $\mathrm{Xu}$ and Hafid Aglzim with Subatech and Thi-Hong-Hanh Le with the Chemistry 701 Institute of Nice for their valuable assistance during the sampling campaigns. 
702

703

704

705

706

707

708

709

710

711

712

713

714

715

716

717

718

719

720

721

722

\section{References}

Abdelouas, A., 2006. Uranium mill tailings: Geochemistry, mineralogy, and environmental impact. Elements 2, 335-341. https://doi.org/10.2113/gselements.2.6.335

Alessi, D.S., Uster, B., Veeramani, H., Suvorova, E.I., Lezama-Pacheco, J.S., Stubbs, J.E., Bargar, J.R., Bernier-Latmani, R., 2012. Quantitative Separation of Monomeric U(IV) from UO2 in Products of U(VI) Reduction. Environ. Sci. Technol. 46, 6150-6157. https://doi.org/10.1021/es204123z

Ballini, M., Chautard, C., Nos, J., Phrommavanh, V., Beaucaire, C., Besancon, C., Boizard, A., Cathelineau, M., Peiffert, C., Vercouter, T., Vors, E., Descostes, M., 2020. A multi-scalar study of the long-term reactivity of uranium mill tailings from Bellezane site (France). J. Environ. Radioact. 218, 106223. https://doi.org/10.1016/j.jenvrad.2020.106223

Beramendi-Orosco, L.E., Rodriguez-Estrada, M.L., Morton-Bermea, O., Romero, F.M., Gonzalez-Hernandez, G., Hernandez-Alvarez, E., 2013. Correlations between metals in tree-rings of Prosopis julifora as indicators of sources of heavy metal contamination. Appl. Geochemistry 39, 78-84. https://doi.org/10.1016/j.apgeochem.2013.10.003

Bister, S., Birkhan, J., Lüllau, T., Bunka, M., Solle, A., Stieghorst, C., Riebe, B., Michel, R., Walther, C., 2015. Impact of former uranium mining activities on the floodplains of the Mulde River, Saxony, Germany. J. Environ. Radioact. 144, 21-31. https://doi.org/10.1016/J.JENVRAD.2015.02.024

Bollhöfer, A., 2012. Stable lead isotope ratios and metals in freshwater mussels from a uranium mining environment in Australia's wet-dry tropics. Appl. Geochemistry 27, 
724 Bollhöfer, A., Honeybun, R., Rosman, K., Martin, P., 2006. The lead isotopic composition of

725

726

727

728

729

730

731

732

733

734

735

736

737

738

739

740

741 dust in the vicinity of a uranium mine in northern Australia and its use for radiation dose assessment. Sci. Total Environ. 366, 579-589. https://doi.org/10.1016/J.SCITOTENV.2005.11.016

Bordelet, G., Beaucaire, C., Phrommavanh, V., Descostes, M., 2018. Chemical reactivity of natural peat towards $U$ and Ra. Chemosphere 202, 651-660. https://doi.org/10.1016/j.chemosphere.2018.03.140

Bretagnolle, V., Benoit, M., Bonnefond, M., Breton, V., Church, J.M., Gaba, S., Gilbert, D., Gillet, F., Glatron, S., Guerbois, C., Lamouroux, N., Lebouvier, M., Mazé, C., Mouchel, J.M., Ouin, A., Pays, O., Piscart, C., Ragueneau, O., Servain, S., Spiegelberger, T., Fritz, H., 2019. Action-orientated research and framework: insights from the French longterm social-ecological research network. Ecol. Soc. 24. https://doi.org/10.5751/ES-10989240310

Chautard, C., Beaucaire, C., Gerard, M., Roy, R., Savoye, S., Descostes, M., 2020. Geochemical characterization of uranium mill tailings (Bois Noirs Limouzat, France) highlighting the $\mathrm{U}$ and 226Ra retention. J. Environ. Radioact. 218. https://doi.org/10.1016/j.jenvrad.2020.106251

Cumberland, S.A., Douglas, G., Grice, K., Moreau, J.W., 2016. Uranium mobility in organic matter-rich sediments: A review of geological and geochemical processes. Earth-Science Rev. 159, 160-185. https://doi.org/10.1016/J.EARSCIREV.2016.05.010 
744 Cumming, G.L., Richards, J.R., 1975. Ore lead isotope ratios in a continuously changing earth.

$745 \quad$ Earth Planet. Sci. Lett. 28, 155-171.

746 Cutter, B.E., Guyette, R.P., 1993. Anatomical, Chemical, and Ecological Factors Affecting Tree 747 Species Choice in Dendrochemistry Studies. J. Environ. Qual. 22, 611-619. $748 \quad$ https://doi.org/10.2134/jeq1993.00472425002200030028x

749 Cuvier, A., Pourcelot, L., Probst, A., Prunier, J., Le Roux, G., 2016. Trace elements and Pb 750 isotopes in soils and sediments impacted by uranium mining. Sci. Total Environ. 566751 567, 238-249. https://doi.org/10.1016/J.SCITOTENV.2016.04.213

752 Déjeant, A., Galoisy, L., Roy, R., Calas, G., Boekhout, F., Phrommavanh, V., Descostes, M., 753 754 755

Edmands, J.D., Brabander, D.J., Coleman, D.S., 2001. Uptake and mobility of uranium in black 757 758

Gourgiotis, A., Mangeret, A., Manhès, G., Blanchart, P., Stetten, L., Morin, G., Le Pape, P., 760 oaks: Implications for biomonitoring depleted uranium-contaminated groundwater. Chemosphere 44, 789-795. https://doi.org/10.1016/S0045-6535(00)00376-3 2016. Evolution of uranium distribution and speciation in mill tailings, COMINAK Mine, $\begin{array}{llll}\text { Niger. Sci. } & \text { Total } & \text { 545iron. }\end{array}$ https://doi.org/10.1016/j.scitotenv.2015.12.027 
Guiollard, P.-C., 2002. L'uranium du Morvan et du Forez.

766

767

768

769

770

771

772

Himeur, N., 2010. Bilan environnemental sites miniers de du Puy-de-Dôme.

777 Himeur, N., Andres, C., 2012. Suivi environnemental du site de Rophin - communes de $778 \quad$ Lachaux et Ris.

779 IAEA, 1998. 137Cs use in estimating soil erosion: 30 years of research. IAEA TECDOC-1028. 780 Int. At. Energy Agency 13-16.

781

IRSN, 2018. IRSN MIMAUSA database, Memory and Impact of uranium mines: synthesis and 782 records [WWW Document]. URL https://mimausabdd.irsn.fr/

783 IRSN, 2014. Report on the Radiological State of the Environment in France in 2010-2011.

784 Jonsson, A., Eklund, M., Håkansson, K., 1997. Heavy Metals of the 20th Century Recorded in 
Oak Tree Rings. J. Environ. Qual. 26, 1638.

787

788

789

790

791

792

793

794

795

796

797

798

799

800

801

802

803

804

805

Larsson, 2016. CDendro \& CooRecorder Program Package for Tree Ring Measurements and Crossdating of the Data [WWW Document]. URL http://www.cybis.se/forfun/dendro/

Le Berre, S., Bretesché, S., 2019. Having a high-risk job: Uranium miners' perception of occupational risk in France. Extr. Ind. Soc. https://doi.org/10.1016/J.EXIS.2019.11.011

Lepp, N.W., 1975. The potential of tree-ring analysis for monitoring heavy metal pollution patterns. Environ. Pollut. 9, 49-61. https://doi.org/10.1016/0013-9327(75)90055-5

Li, D., Seaman, J.C., Chang, H.-S., Jaffe, P.R., Koster van Groos, P., Jiang, D.-T., Chen, N., Lin, J., Arthur, Z., Pan, Y., Scheckel, K.G., Newville, M., Lanzirotti, A., Kaplan, D.I., 2014. Retention and chemical speciation of uranium in an oxidized wetland sediment from the Savannah River Site. J. Environ. Radioact. 131, 40-46. https://doi.org/10.1016/J.JENVRAD.2013.10.017

Ljungberg, J., Öhlander, B., 2001. The geochemical dynamics of oxidising mine tailings at Laver, northern Sweden. J. Geochemical Explor. 74, 57-72. https://doi.org/https://doi.org/10.1016/S0375-6742(01)00175-3

Lottermoser, B.G., Ashley, P.M., 2005. Tailings dam seepage at the rehabilitated Mary Kathleen uranium mine, Australia. J. Geochemical Explor. 85, 119-137. https://doi.org/10.1016/j.gexplo.2005.01.001

Lovley, D.R., Phillips, E.J.P., Gorby, Y.A., Landa, E.R., 1991. Microbial reduction of uranium. Nature 350, 413-416. https://doi.org/10.1038/350413a0 
806

807

808

809

810

811

812

813

814

815

816

817

Mangeret, A., Blanchart, P., Alcalde, G., Amet, X., Cazala, C., Gallerand, M.-O., 2018. An evidence of chemically and physically mediated migration of $238 \mathrm{U}$ and its daughter isotopes in the vicinity of a former uranium mine. J. Environ. Radioact. 195, 67-71. https://doi.org/10.1016/J.JENVRAD.2018.08.018

Märten, A., Berger, D., Köhler, M., Merten, D., 2015. The dendroanalysis of oak trees as a method of biomonitoring past and recent contamination in an area influenced by uranium mining. Environ. Sci. Pollut. Res. 22, 19417-19425. https://doi.org/10.1007/s11356-015-4902-z

Mikutta, C., Langner, P., Bargar, J.R., Kretzschmar, R., 2016. Tetra- and Hexavalent Uranium Forms Bidentate-Mononuclear Complexes with Particulate Organic Matter in a Naturally Uranium-Enriched Peatland. Environ. Sci. Technol. 50, 10465-10475. https://doi.org/10.1021/acs.est.6b03688

Monticelli, D., Di lorio, A., Ciceri, E., Castelletti, A., Dossi, C., 2009. Tree ring microanalysis by LA-ICP-MS for environmental monitoring: Validation or refutation? Two case histories. Microchim. Acta 164, 139-148. https://doi.org/10.1007/s00604-008-0049-7

Nabaisa, C., Freitasa, H., Hagemeyerb, J., 1999. Dendroanalysis: A tool for biomonitoring environmental pollution? Sci. Total Environ. 232, 33-37. https://doi.org/10.1016/S0048-9697(99)00107-2

Nakashima, S., Disnar, J.R., Perruchot, A., Trichet, J., 1984. Experimental study of mechanisms of fixation and reduction of uranium by sedimentary organic matter under diagenetic or hydrothermal conditions. Geochim. Cosmochim. Acta 48, 2321-2329. https://doi.org/10.1016/0016-7037(84)90228-X 
828 Newsome, L., Morris, K., Shaw, S., Trivedi, D., Lloyd, J.R., 2015. The stability of microbially 829 reduced U(IV); impact of residual electron donor and sediment ageing. Chem. Geol. 830 409, 125-135. https://doi.org/10.1016/J.CHEMGEO.2015.05.016

831 Owen, D.E., Otton, J.K., 1995. Mountain wetlands: Efficient uranium filters - potential 832 impacts. Ecol. Eng. 5, 77-93. https://doi.org/10.1016/0925-8574(95)00013-9

833 Pearson, C., Manning, S.W., Coleman, M., Jarvis, K., 2005. Can tree-ring chemistry reveal 834 absolute dates for past volcanic eruptions? J. Archaeol. Sci. 32, 1265-1274. 835 https://doi.org/10.1016/J.JAS.2005.03.007

836 Péron, O., Gégout, C., Reeves, B., Rousseau, G., Montavon, G., Landesman, C., 2016. 837 Anthropogenic tritium in the Loire River estuary, France. J. Sea Res. 118, 69-76. 838 https://doi.org/10.1016/j.seares.2016.04.003

839 Perone, A., Cocozza, C., Cherubini, P., Bachmann, O., Guillong, M., Lasserre, B., Marchetti, 840 M., Tognetti, R., 2018. Oak tree-rings record spatial-temporal pollution trends from 841 different sources in Terni (Central Italy). Environ. Pollut. 233, 278-289. 842 https://doi.org/10.1016/J.ENVPOL.2017.10.062

843 Ramsey, C.B., 2017. Methods for Summarizing Radiocarbon Datasets. Radiocarbon 59, 1809844 1833. https://doi.org/10.1017/RDC.2017.108

Regenspurg, S., Margot-Roquier, C., Harfouche, M., Froidevaux, P., Steinmann, P., Junier, P., 846 Bernier-Latmani, R., 2010. Speciation of naturally-accumulated uranium in an organic847 rich soil of an alpine region (Switzerland). Geochim. Cosmochim. Acta 74, 2082-2098. 848 https://doi.org/10.1016/J.GCA.2010.01.007 
849

Reimer, P.J., Bard, E., Bayliss, A., Beck, J.W., Blackwell, P.G., Ramsey, C.B., Buck, C.E., Cheng, H., Edwards, R.L., Friedrich, M., Grootes, P.M., Guilderson, T.P., Haflidason, H., Hajdas, I., Hatté, C., Heaton, T.J., Hoffmann, D.L., Hogg, A.G., Hughen, K.A., Kaiser, K.F., Kromer, B., Manning, S.W., Niu, M., Reimer, R.W., Richards, D.A., Scott, E.M., Southon, J.R., Staff, R.A., Turney, C.S.M., van der Plicht, J., 2013. IntCal13 and Marine13 Radiocarbon Age Calibration Curves 0-50,000 Years cal BP. Radiocarbon 55, 1869-1887. https://doi.org/DOI: 10.2458/azu_js_rc.55.16947

Reyss, J.L., Mangeret, A., Courbet, C., Bassot, S., Alcalde, G., Thouvenot, A., Guillevic, J., 2016. Estimation of sedimentation rates based on the excess of radium 228 in granitic reservoir sediments. J. Environ. Radioact. 162-163, 8-13. https://doi.org/10.1016/j.jenvrad.2016.04.032

Salpeteur, I., Angel, J.-M., 2010. Geochemical baseline data for trace elements in surface water and active sediment from French rivers collected by the FOREGS Geochemical Atlas of Europe (I). Environnement, Risques \& Santé 9, 121-135. https://doi.org/10.1684/ers.2010.0332

Sansone, U., Roberto Danesi, P., Barbizzi, S., Belli, M., Campbell, M., Gaudino, S., Jia, G., Ocone, R., Pati, A., Rosamilia, S., Stellato, L., 2001. Radioecological survey at selected sites hit by depleted uranium ammunitions during the 1999 Kosovo conflict. Sci. Total Environ. 281, 23-35. https://doi.org/10.1016/S0048-9697(01)01034-8

Schöner, A., Noubactep, C., Sauter, M., 2009. Geochemistry of natural wetlands in former uranium milling sites (eastern Germany) and implications for uranium retention. Geochemistry 69, 91-107. https://doi.org/10.1016/J.CHEMER.2007.12.003 
871 Stacey, J.S., Kramers, J.D., 1975. Approximation of terrestrial lead isotope evolution by a 872 two-stage model. Earth Planet. Sci. Lett. 26, 207-221. https://doi.org/10.1016/0012$873 \quad 821 \times(75) 90088-6$

874 Tedjani, A., Mavon, C., Belafrites, A., Degrelle, D., Boumala, D., Rius, D., Groetz, J.-E., 2016. 875 Well GeHP detector calibration for environmental measurements using reference materials. Nucl. Instruments Methods Phys. Res. Sect. A Accel. Spectrometers, Detect.

878 Wang, Y., Bagnoud, A., Suvorova, E., McGivney, E., Chesaux, L., Phrommavanh, V., Descostes, 879 M., Bernier-Latmani, R., 2014. Geochemical Control on Uranium(IV) Mobility in a 880 Mining-Impacted Wetland. Environ. Sci. Technol. 48, 10062-10070. 881 https://doi.org/10.1021/es501556d

882 Watmough, S.A., Hutchinson, T.C., 1996. Analysis of tree rings using inductively coupled 883 plasma mass spectrometry to record fluctuations in a metal pollution episode. Environ. 884 Pollut. 93, 93-102. https://doi.org/10.1016/0269-7491(95)00107-7

885 Zielinski, R.A., Bush, C.A., Rosholt, J.N., 1986. Uranium series disequilibrium in a young 886 surficial uranium deposit, northeastern Washington, U.S.A. Appl. Geochemistry 1, 503887 511. https://doi.org/10.1016/0883-2927(86)90055-7 